Article

\title{
Characterizing Greenhouse Gas Emissions and Global Warming Potential of Wheat-Maize Cropping Systems in Response to Organic Amendments in Eutric Regosols, China
}

\author{
Hamidou Bah ${ }^{1,2,3}$, Xiao Ren ${ }^{1}$, Yanqiang Wang ${ }^{1}$, Jialiang Tang ${ }^{1}\left[\right.$ and Bo Zhu ${ }^{1, *}$ \\ 1 Key Laboratory of Mountain Surface Processes and Ecological Regulation, Institute of Mountain Hazards and \\ Environment, Chinese Academy of Sciences, Chengdu 610041, China; bahamidou2004@imde.ac.cn (H.B.); \\ renxiao@imde.ac.cn (X.R.); yanqiang_wang@imde.ac.cn (Y.W.); jltang@imde.ac.cn (J.T.) \\ 2 International College, University of Chinese Academy of Sciences, Beijing 100049, China \\ 3 Institute Superior of Agronomy and Veterinary of Faranah (ISAV/F), Faranah 131, Guinea \\ * Correspondence: bzhu@imde.ac.cn
}

Received: 8 May 2020; Accepted: 8 June 2020; Published: 10 June 2020

check for updates

\begin{abstract}
Characterizing greenhouse gas (GHG) emissions and global warming potential (GWP) has become a key step in the estimation of atmospheric GHG concentrations and their potential mitigation by cropland management. However, the impacts of organic amendments on GHG, GWP, and yield-scaled GWP on cropland have not been well documented. Here, we investigate four amendment treatments (no amendment, mineral fertilizers, and pig slurry or crop residue combined with mineral fertilizers) during a two-year field experiment in rain-fed wheat-maize cropping systems. The results show that the average annual cumulative methane $\left(\mathrm{CH}_{4}\right)$ flux ranged from -2.60 to $-2.97 \mathrm{~kg} \cdot \mathrm{C} \cdot \mathrm{ha}^{-1}$ while nitrous oxide $\left(\mathrm{N}_{2} \mathrm{O}\right)$ flux ranged from 0.44 to $4.58 \mathrm{~kg} \cdot \mathrm{N} \cdot \mathrm{ha} \mathrm{a}^{-1}$ across all four treatments. $\mathrm{N}_{2} \mathrm{O}$ emissions were significantly correlated with soil inorganic nitrogen (i.e., $\mathrm{NH}_{4}{ }^{+}-\mathrm{N}$ and $\mathrm{NO}_{3}{ }^{-}-\mathrm{N}$ ), and soil dissolved organic carbon (DOC) during both the winter wheat and summer maize seasons. On average, organic amendments combined with mineral fertilizers increased the annual GWP by $26-74 \%$ and yield-scaled GWP by $19-71 \%$ compared to those under only mineral fertilizers application. This study indicates that the fertilization strategy for Eutric Regosols can shift from only mineral fertilizers to organic amendments combined with mineral fertilizers, which can help mitigate GHG emissions and GWP while maintaining crop yields.
\end{abstract}

Keywords: organic fertilizers; $\mathrm{CH}_{4}$ emissions; $\mathrm{N}_{2} \mathrm{O}$ emissions; global warming potential; Eutric Regosols

\section{Introduction}

Wheat and maize are among the main sources of carbohydrates for human consumption; accordingly, the production of these grains is expected to increase by $1.3 \%$ per year by $2025[1,2]$. Along with the growing increase in carbohydrate demand, the production of cereal grains, such as wheat and maize, must be continued, while more land will require agricultural and fertilizer applications to sustain productivity. To reduce mineral nitrogen $(\mathrm{N})$ fertilizers use and subsequent soil degradation, organic soil amendments are being more widely applied [3].

For over two decades reports have shown that the world's food production occurs in $37 \%$ of its total land area, and, as a consequence, agricultural practices have become a key source of methane $\left(\mathrm{CH}_{4}\right)$ and nitrous oxide $\left(\mathrm{N}_{2} \mathrm{O}\right)$ emissions, representing $50 \%$ of anthropogenic $\mathrm{CH}_{4}$ and $60 \%$ of anthropogenic $\mathrm{N}_{2} \mathrm{O}$ emissions globally [4-6]. The extensive application of mineral $\mathrm{N}$ fertilizers and organic materials 
(i.e., manure and crop residue) to soil for crop production purposes is responsible for the increased $\mathrm{CH}_{4}$ and $\mathrm{N}_{2} \mathrm{O}$ emissions from agricultural practices [7-9]. According to Ravishankara and colleagues [7], $\mathrm{CH}_{4}$ and $\mathrm{N}_{2} \mathrm{O}$ emissions from agriculture contribute approximately $20 \%$ to global radiative forcing. $\mathrm{N}_{2} \mathrm{O}$ is a strong greenhouse gas with a high potential to deplete the ozone layer $[7,10]$.

Generally, if integrated with crop nutrient demands, organic amendment application to agricultural soil can lead to the creation of small $\mathrm{CH}_{4}$ sinks $[8,11,12]$. Conversely, the application of organic amendments over a long period can potentially affect $\mathrm{CH}_{4}$ and $\mathrm{N}_{2} \mathrm{O}$ emissions $[9,13,14]$. Specifically, an increase in $\mathrm{N}_{2} \mathrm{O}$ emissions from organic amendments could occur via nitrification and denitrification processes $[12,15,16]$. Therefore, soil temperature and soil moisture could both strongly affect $\mathrm{N}_{2} \mathrm{O}$ emissions $[8,9,13]$.

The soil locally called "purplish soil" is classified as a Eutric Regosol under the United Nations (UN) Food and Agriculture Organization (FAO) system and a Pup-Orthic-Entisol under the Chinese Soil Taxonomy system [17]. Purplish soil comprises an area of $160,000 \mathrm{~km}^{2}$ in the upper reaches of the Yangtze River [18], accounting for $68 \%$ of the total cropland in Sichuan Province and 7\% of China's total cropland area [19]. Purplish soil is typically fertile, with a relatively high mineral content [19]. Owing to its low organic matter content and high mineral content, purplish soil is liable to generate $\mathrm{N}_{2} \mathrm{O}$ emissions, particularly under intensive mineral $\mathrm{N}$ fertilizer applications [20]. Additionally, Zhou et al. [12] reported that the combination of organic amendments and mineral $\mathrm{N}$ fertilizer application could result in the creation of small $\mathrm{CH}_{4}$ sinks with annual soil $\mathrm{CH}_{4}$ emissions of -2.1 to $-1.8 \mathrm{~kg} \cdot \mathrm{C} \cdot \mathrm{ha}^{-1}$. Furthermore, previous studies conducted on $\mathrm{N}_{2} \mathrm{O}$ emissions from purplish soil demonstrated that mineral $\mathrm{N}$ fertilizer application at a rate of $250 \mathrm{~kg} \mathrm{~N} \mathrm{ha}{ }^{-1} \cdot \mathrm{yr}^{-1}$ in wheat-maize cropping systems will lead to an annual $\mathrm{N}_{2} \mathrm{O}$ flux of 1.9 to $6.7 \mathrm{~kg} \cdot \mathrm{N} \cdot \mathrm{ha}^{-1} \cdot \mathrm{yr}^{-1}$, which corresponds to an emission factor $\left(\mathrm{EF}_{\mathrm{d}}\right)$ of $0.12-1.06 \%$ [21].

Given the aim of reducing combined $\mathrm{CH}_{4}$ and $\mathrm{N}_{2} \mathrm{O}$ emissions under the objective of maintaining crop yields, the global warming potential (GWP) values of 28 for $\mathrm{CH}_{4}$ and 265 for $\mathrm{N}_{2} \mathrm{O}$ over a 100-year planning horizon [10] should be taken into account prior to making the shift from mineral fertilizers to organic amendment applications [8]. GWP can alternatively be viewed as a crop yield function, referred to as yield-scaled GWP, with which to evaluate $\mathrm{CH}_{4}$ and $\mathrm{N}_{2} \mathrm{O}$ emission mitigation under the objective of maintaining crop grain yields [2,22]. However, very few studies have concurrently reported on GWP or yield-scaled GWP and the release of $\mathrm{CH}_{4}$ and $\mathrm{N}_{2} \mathrm{O}$ emissions under organic amendment applications in wheat-maize cropping systems. Thus, determining the GWP of $\mathrm{CH}_{4}$ and $\mathrm{N}_{2} \mathrm{O}$ emissions under organic amendment applications in Eutric Regosols could be important for estimating potential $\mathrm{CH}_{4}$ and $\mathrm{N}_{2} \mathrm{O}$ emission effects on regional and global climate systems. Accordingly, the aims of this study were (1) to quantify $\mathrm{CH}_{4}$ and $\mathrm{N}_{2} \mathrm{O}$ emissions under different organic amendments in wheat-maize rotational cropping systems, and (2) to determine the GWP of $\mathrm{CH}_{4}$ and $\mathrm{N}_{2} \mathrm{O}$ emissions and associated yield-scaled GWP in order to find the most suitable management practices for organic amendment applications to Eutric Regosols in the Sichuan Basin, China.

\section{Experiments}

\subsection{Site Conditions}

The Yanting Agro-Ecological Station of Purplish Soil $\left(31^{\circ} 16^{\prime}\right.$ N, $105^{\circ} 28^{\prime}$ E, 420 m a.s.l., Southwest China) was selected as the location of the field experiment. This research station is under the auspice of the Chinese Ecosystem Research Network (CERN). The climate is a moderately subtropical monsoon climate. The annual average air temperature is $17.3^{\circ} \mathrm{C}$, and the annual precipitation is $826 \mathrm{~mm}$ [14]. The soil is $19.2 \%$ clay, $42.1 \%$ silt, and $38.7 \%$ sand; the $\mathrm{pH}$ level is 8.22 (with a water/soil ratio of $2.5: 1$ $w / w)$; the bulk density (BD) is $1.32 \mathrm{~g} \cdot \mathrm{cm}^{-3}$; the organic carbon (C) content is $8.75 \mathrm{~g} \cdot \mathrm{kg}^{-1}$; and the total $\mathrm{N}$ content is $0.62 \mathrm{~g} \cdot \mathrm{kg}^{-1}[19]$. 


\subsection{Experimental Design}

A randomized lysimeter-based block design was used for this experiment (size: $8 \times 4 \mathrm{~m}^{2}$ ). Four treatments (including three replicates) with long-term fertilization were established in 2002 using a winter wheat and summer maize rotational system. The four treatments were as follows: (1) no amendment (CK) (i.e., the control), (2) mineral fertilizers (NPK), (3) pig slurry (mineral N application rate $=40 \%$ ) combined with mineral fertilizers (mineral $\mathrm{N}$ application rate $=60 \%$ ) (OMNPK), and (4) crop residue (mineral $\mathrm{N}$ application rate $=20 \%$ ) combined with mineral fertilizers (mineral $\mathrm{N}$ application rate $=80 \%)\left(\right.$ CRNPK). Except for the control (CK), all treatments were amended with $280 \mathrm{~kg} \cdot \mathrm{N} \cdot \mathrm{ha}^{-1}$ annually, which were subdivided into $130 \mathrm{~kg} \cdot \mathrm{N} \cdot \mathrm{ha}^{-1}$ during the winter wheat (Triticum aestivum L.) season and $150 \mathrm{~kg} \cdot \mathrm{N} \cdot \mathrm{ha}^{-1}$ during the summer maize (Zea mays L.) season. The mineral fertilizers used were urea $\left(\mathrm{NH}_{4} \mathrm{HCO}_{3}\right)$ for $\mathrm{N}$, calcium superphosphate $\left(\mathrm{Ca}\left(\mathrm{H}_{2} \mathrm{PO}_{4}\right)_{2}\right)$ at $90 \mathrm{~kg} \mathrm{P}_{2} \mathrm{O}_{5} \mathrm{ha}^{-1}$ for phosphorus $(\mathrm{P})$, and potassium chloride $(\mathrm{KCl})$ at $36 \mathrm{~kg} \mathrm{~K}_{2} \mathrm{O} \mathrm{ha}^{-1}$ for potassium $(\mathrm{K})$, which were utilized as basal fertilizers for both the winter wheat and summer maize cropping seasons. Pig slurry procured from a single pig farm was utilized for both crops (i.e., wheat and maize). The total $\mathrm{N}$ content of the pig slurry used as fertilizer under both crop rotations ranged from 15 to $16 \mathrm{mg} \cdot \mathrm{kg}^{-1}$, while the total C content ranged from 350 to $338 \mathrm{mg} \cdot \mathrm{kg}^{-1}$, for an average C:N ratio of 22.0. Both wheat and maize crop residues were used in this experiment, with total $\mathrm{N}$ contents of $5.6 \mathrm{mg} \cdot \mathrm{kg}^{-1}$ and $9.2 \mathrm{mg} \cdot \mathrm{kg}^{-1}$, total C contents of $429.1 \mathrm{mg} \cdot \mathrm{kg}^{-1}$ and $415.3 \mathrm{mg} \cdot \mathrm{kg}^{-1}$, and average C:N ratios of 76.6 and 45.1 , respectively. Every year, wheat (variety 01-3570) was sown in early November and harvested in late May for the winter wheat cropping season, while maize (variety Chengdan 60) was planted in early June and harvested late September for the maize cropping season.

\subsection{Soil Measurements}

Samples used to determine soil ammonia nitrogen $\left(\mathrm{NH}_{4}{ }^{+}-\mathrm{N}\right)$, nitrate nitrogen $\left(\mathrm{NO}_{3}{ }^{-}-\mathrm{N}\right)$, and dissolved organic carbon (DOC) content were collected from the plots at each gas sampling event. Moreover, soil samples were collected randomly from three positions in each plot (at a $20 \mathrm{~cm}$ depth) using a small stainless-steel flat-blade shovel. Following sampling, plastic bags were used to promptly seal the soil samples, which were then stored at $4{ }^{\circ} \mathrm{C}$ until analysis. In the laboratory, $25 \mathrm{~mL}$ of a $0.5 \mathrm{M}$ $\mathrm{K}_{2} \mathrm{SO}_{4}$ solution were used to extract soil samples $(5 \pm 0.5 \mathrm{~g})$, after which $0.45 \mu \mathrm{m}$ membranes were used to filter the supernatant. Following this, an Auto Analyzer-AA3 (Bran + Luebbe, Norderstedt, Germany) was used to analyze the $\mathrm{NH}_{4}{ }^{+}-\mathrm{N}, \mathrm{NO}_{3}{ }^{-}-\mathrm{N}$, and DOC contents in the filtrates.

\subsection{Crop Yield Measurements}

Crop yields in all treatments $\left(0.25 \mathrm{~m}^{2}\right.$ wheat harvest plots and $1 \mathrm{~m}^{2}$ maize plots $)$ and replicates were measured during harvest. After biomass harvesting, grains were separated and then oven-dried at $70{ }^{\circ} \mathrm{C}$ for $48 \mathrm{~h}$ to determine their dry weight equivalent grain yield $\left(\mathrm{Mg}^{\circ} \cdot \mathrm{ha}^{-1}\right)$.

\subsection{Soil $\mathrm{CH}_{4}$ and $\mathrm{N}_{2} \mathrm{O}$ Emission Measurements}

Emissions of $\mathrm{CH}_{4}$ and $\mathrm{N}_{2} \mathrm{O}$ were measured at the same time over a two-year period (i.e., from November 2016 to October 2018) using static chamber-gas chromatography, which had previously been used in a similar observational study conducted by Zhou and co-workers [8]. After plowing the field plots and prior to planting the crops, we inserted a stainless-steel chamber on a permanent collar $(0.50 \times 0.50 \mathrm{~m})$ into the soil of each plot at a $10 \mathrm{~cm}$ depth, which remained in place throughout the entire wheat-maize rotational experimental period. The chambers were encased in a layer of insulating material to minimize exposure to temperature fluctuations when the chambers were in a closed position. The aboveground height of the chamber collar was adjusted according to the specific wheat-maize growth stage, and a circulating fan was used to guarantee uniform mixing within the chamber headspace. We measured $\mathrm{CH}_{4}$ and $\mathrm{N}_{2} \mathrm{O}$ fluxes daily during the first week following fertilization, after which $\mathrm{CH}_{4}$ and $\mathrm{N}_{2} \mathrm{O}$ fluxes were measured at 2-day intervals 
during the second week. Thereafter, the sampling frequency was set to twice weekly for the remainder of the measurement period.

Gas samples were collected from the chambers during morning hours (i.e., from 9:00 to 11:00 am) following the procedure recommended by Parkin and Venterea [23]. After closure, five separate gas samples were collected at each flux measurement, using $50 \mathrm{~mL}$ plastic syringes that were fitted with three-way stopcocks inserted into Teflon tubes fixed to the chambers. Throughout the gas sampling stage of our experiment, a manual thermoelectric thermometer (model JM624, Tianjin Jinming Instrument Co. Ltd., Tianjin, China) was used to measure both chamber temperature and soil temperature. A portable frequency domain reflectometry probe (RDS Technology Co. Ltd., Nanjing, Jiangsu, China) was used in the same manner to measure soil moisture (soil volumetric water content), which was then converted into water-filled pore space (WFPS in \%) as shown in Equation (1).

After sampling, a gas chromatograph (GC) (HP 5890II, Hewlett-Packard, Palo Alto, CA, USA) rigged with a flame ionization detector (FID) was used to analyze $\mathrm{CH}_{4}$ flux and an electron capture detector (ECD) was used to analyze $\mathrm{N}_{2} \mathrm{O}$ flux in gas samples. This study used the inclusive GC configuration procedure by Wang and Wang [24] for $\mathrm{CH}_{4}$ and $\mathrm{N}_{2} \mathrm{O}$ gas analysis. We used high purity dinitrogen $\left(\mathrm{N}_{2}\right)$ as a gas carrier and did not directly introduce a high concentration buffering gas such as $\mathrm{CO}_{2}$ and $\mathrm{CH}_{4}$ into the detector for analysis. For each measurement, the system was calibrated with known mixed gas concentrations of $0.5 \mathrm{ppm} \mathrm{N}_{2} \mathrm{O}, 5.1 \mathrm{ppm} \mathrm{CH}_{4}$, and $386.2 \mathrm{ppm} \mathrm{CO}_{2}$.

\subsection{Calculations}

For this study, we expressed soil moisture as WFPS (\%). It was calculated following Equation (1):

$$
W F P S=S V W C \times \frac{B D}{1-\left(\frac{B D}{2.65}\right)} \times 100
$$

where SVWC (\%) is the soil volumetric water content; $B D$ is the soil bulk density; and $2.65 \mathrm{~g} \cdot \mathrm{cm}^{3}$ is the theoretical particle density.

$\mathrm{CH}_{4}$ and $\mathrm{N}_{2} \mathrm{O}$ fluxes from soil were calculated following the method suggested by Wang and Wang [24], while cumulative seasonal and annual $\mathrm{CH}_{4}$ and $\mathrm{N}_{2} \mathrm{O}$ fluxes were calculated using daily flux linear interpolation between gas sampling rates following the method of Gao et al. [25]:

We calculated direct $\mathrm{N}_{2} \mathrm{O}$ emission factors $\left(E F_{d} ; \%\right)$ generated by the $\mathrm{N}$ fertilizer applied in each treatment using Equation (2):

$$
E F_{d}(\%)=100 \times \frac{E_{F}-E_{O}}{\mathrm{~N}}
$$

where $E_{F}$ denotes cumulative $\mathrm{N}_{2} \mathrm{O}$ emissions from the $\mathrm{N}$ fertilizer treatments $\left(\mathrm{kg} \cdot \mathrm{N} \cdot \mathrm{ha}{ }^{-1}\right) ; E_{O}$ denotes cumulative $\mathrm{N}_{2} \mathrm{O}$ emissions in the unfertilized treatment (CK, the control) $\left(\mathrm{kg} \cdot \mathrm{N} \cdot \mathrm{ha}{ }^{-1}\right)$; and $\mathrm{N}$ denotes the $\mathrm{N}$ fertilizer application rate $\left(\mathrm{kg} \cdot \mathrm{N} \cdot \mathrm{ha}^{-1}\right)$.

To better understand the effects of different organic fertilization practices on $\mathrm{N}_{2} \mathrm{O}$ and $\mathrm{CH}_{4}$ emissions, the corresponding GWP $\mathrm{CO}_{2}$ equivalents $\left(\mathrm{CO}_{2}\right.$-eq $\left.\mathrm{kg} \cdot \mathrm{ha}{ }^{-1}\right)$ were calculated based on a 100-year planned horizon. The results showed that the GWP value of $\mathrm{CH}_{4}$ was 28 and the GWP value of $\mathrm{N}_{2} \mathrm{O}$ was 265 [10]. Equation (3) was used to determine these values:

$$
\text { GWP }=28 \times \mathrm{CH}_{4}+265 \times \mathrm{N}_{2} \mathrm{O}
$$

where GWP is expressed as $\mathrm{kg} \mathrm{CO}$-eq $\cdot \mathrm{kg}^{-1}$, and $\mathrm{CH}_{4}$ and $\mathrm{N}_{2} \mathrm{O}$ fluxes are expressed as $\mathrm{kg} \cdot \mathrm{ha}^{-1} \cdot \mathrm{yr}^{-1}$.

The yield-scaled GWP $\left(\mathrm{kg} \mathrm{CO}_{2}\right.$-eq. $\left.\mathrm{kg}^{-1}\right)$ of $\mathrm{N}_{2} \mathrm{O}$ and $\mathrm{CH}_{4}$ emission fluxes was calculated by subdividing GWP by the wheat-maize grain yield of each treatment [22]. 


\subsection{Statistical Analysis}

Statistical analysis was used to verify the effects of the four treatments on $\mathrm{CH}_{4}$ and $\mathrm{N}_{2} \mathrm{O}$ emission fluxes, grain yields, GWP, and yield-scaled GWP. This was done using one-way analysis of variance (ANOVA) in SPSS version 16.0 (Chicago, IL, USA). The least significant difference (LSD) test was used to verify significant differences in the means of estimated parameters between all four treatments at a $95 \%$ confidence level $(p<0.05)$. $\mathrm{N}_{2} \mathrm{O}$ emission flux data were log-transformed to meet parametric assumptions associated with normality and homogeneity of variances, while the absolute negative values of $\mathrm{CH}_{4}$ flux transformed to $\mathrm{CH}_{4}$ uptake values were used for regression analysis. Data are provided in triplicate as the means \pm standard error (SE). This study used SigmaPlot (version 12.5; Systat, Inc., Chicago, IL, USA) to construct graphs.

\section{Results}

\subsection{Seasonal Variations in Environmental Factors}

The obvious differences observed in daily precipitation and daily maximum and minimum air temperatures indicated distinct trends between the winter wheat season (Nov/May) and the summer maize season (June/Oct) (Figure 1a). The annual precipitation from 2016 to 2017 and from 2017 to 2018 was $785 \mathrm{~mm}$ and $630 \mathrm{~mm}$, respectively, $70 \%$ of which occurred during the summer maize season. The maximum daily air temperature was $38.2^{\circ} \mathrm{C}$ from 2016 to 2017 and $37.9^{\circ} \mathrm{C}$ from 2017 to 2018, while the minimum daily air temperature was $-2.1^{\circ} \mathrm{C}$ from 2016 to 2017 and $-5.4^{\circ} \mathrm{C}$ from 2017 to 2018 (Figure 1a). The annual mean daily temperature was $17.6^{\circ} \mathrm{C}$ throughout the two-year experimental period (Figure 1a). The soil temperature of the four treatments during the winter wheat season ranged from 4.1 to $23.1{ }^{\circ} \mathrm{C}$, while the mean soil temperature during the summer maize season ranged from 17.6 to $29.6^{\circ} \mathrm{C}$ (Figure $1 \mathrm{~b}$ ) throughout the two-year experimental period. The water-filled pore space (WFPS) of soil throughout the winter wheat growing season varied from 15.7 to $67.1 \%$ for all four treatments, while the WFPS of soil throughout the summer maize season varied from 12.1 to $106.6 \%$ throughout the two-year experimental period (Figure 1b). Table S1 (Supplementary Materials) provides the mean annual seasonal variation in soil temperature and the WFPS of soil for all four treatments throughout the two-year experimental period.

\section{2. $\mathrm{CH}_{4}$ Fluxes}

During both the winter wheat and summer maize seasons, $\mathrm{CH}_{4}$ fluxes subsequently acted as small sinks (Figure 2). During the winter wheat season, the $\mathrm{CH}_{4}$ fluxes varied from -0.10 to $-0.02 \mathrm{mg} \cdot \mathrm{C} \cdot \mathrm{m}^{-2} \cdot \mathrm{hr}^{-1}$ in the $2016 / 2017 \mathrm{cropping}$ season and from -0.08 to $-0.01 \mathrm{mg} \cdot \mathrm{C} \cdot \mathrm{m}^{-2} \cdot \mathrm{hr}^{-1}$ in the 2017/2018 cropping season for CK (Figure 2a); from -0.09 to $-0.01 \mathrm{mg} \cdot \mathrm{C} \cdot \mathrm{m}^{-2} \cdot \mathrm{hr}^{-1}$ in the $2016 / 2017$ cropping season and from -0.17 to $-0.01 \mathrm{mg} \cdot \mathrm{C} \cdot \mathrm{m}^{-2} \cdot \mathrm{hr}^{-1}$ in the $2017 / 2018$ cropping season for NPK (Figure 2b); from -0.12 to $-0.01 \mathrm{mg} \cdot \mathrm{C} \cdot \mathrm{m}^{-2} \cdot \mathrm{hr}^{-1}$ in the $2016 / 2017$ cropping season and from -0.11 to $-0.01 \mathrm{mg} \cdot \mathrm{C} \cdot \mathrm{m}^{-2} \cdot \mathrm{hr}^{-1}$ in the $2017 / 2018$ cropping season for OMNPK (Figure 2c); and from -0.14 to $-0.01 \mathrm{mg} \cdot \mathrm{C} \cdot \mathrm{m}^{-2} \cdot \mathrm{hr}^{-1}$ in the $2016 / 2017$ cropping season and from -0.11 to $-0.01 \mathrm{mg} \cdot \mathrm{C} \cdot \mathrm{m}^{-2} \cdot \mathrm{hr}^{-1}$ in the 2017/2018 cropping season for CRNPK (Figure 2d). The largest $\mathrm{CH}_{4}$ flux peak of $-0.01 \mathrm{mg} \cdot \mathrm{C} \cdot \mathrm{m}^{-2} \cdot \mathrm{hr}^{-1}$ was observed for all four treatments (except for CK in the 2016/2017 cropping season), while the smallest $\mathrm{CH}_{4}$ flux peak was observed in the CRNPK treatment in 2016/2017 and in the NPK treatment in the 2017/2018 cropping season.

Conversely, during the summer maize season, the $\mathrm{CH}_{4}$ fluxes varied from -0.07 to $-0.01 \mathrm{mg} \cdot \mathrm{C} \cdot \mathrm{m}^{-2} \cdot \mathrm{hr}^{-1}$ in both the 2017 and 2018 cropping seasons for CK (Figure 2a); from -0.09 to $-0.01 \mathrm{mg} \cdot \mathrm{C} \cdot \mathrm{m}^{-2} \cdot \mathrm{hr}^{-1}$ in the $2017 \mathrm{cropping}$ season and from -0.09 to $-0.02 \mathrm{mg} \cdot \mathrm{C} \cdot \mathrm{m}^{-2} \cdot \mathrm{hr}^{-1}$ in the 2018 cropping season for NPK (Figure $2 \mathrm{~b}$ ); from -0.27 to $-0.01 \mathrm{mg} \cdot \mathrm{C} \cdot \mathrm{m}^{-2} \cdot \mathrm{hr}^{-1}$ in the 2017 cropping season and from -0.05 to $0.00 \mathrm{mg} \cdot \mathrm{C} \cdot \mathrm{m}^{-2} \cdot \mathrm{hr}^{-1}$ in the 2018 cropping season for OMNPK (Figure 2c); and from -0.06 to $-0.01 \mathrm{mg} \cdot \mathrm{C} \cdot \mathrm{m}^{-2} \cdot \mathrm{hr}^{-1}$ in the $2017 \mathrm{cropping}$ season and from -0.05 to $-0.01 \mathrm{mg} \cdot \mathrm{C} \cdot \mathrm{m}^{-2} \cdot \mathrm{hr}^{-1}$ in the 2018 cropping season for CRNPK (Figure 2d). The largest $\mathrm{CH}_{4}$ flux peak of $-0.01 \mathrm{mg} \cdot \mathrm{C} \cdot \mathrm{m}^{-2} \cdot \mathrm{hr}^{-1}$ 
was observed for all four treatments (except for NPK and OMNPK in the 2018 cropping season), while the smallest $\mathrm{CH}_{4}$ flux peak was observed in the OMNPK treatment in the 2017 cropping season, and in the NPK treatment in the 2018 cropping season. Table S1 (Supplementary Materials) provides the mean seasonal annual $\mathrm{CH}_{4}$ variations.

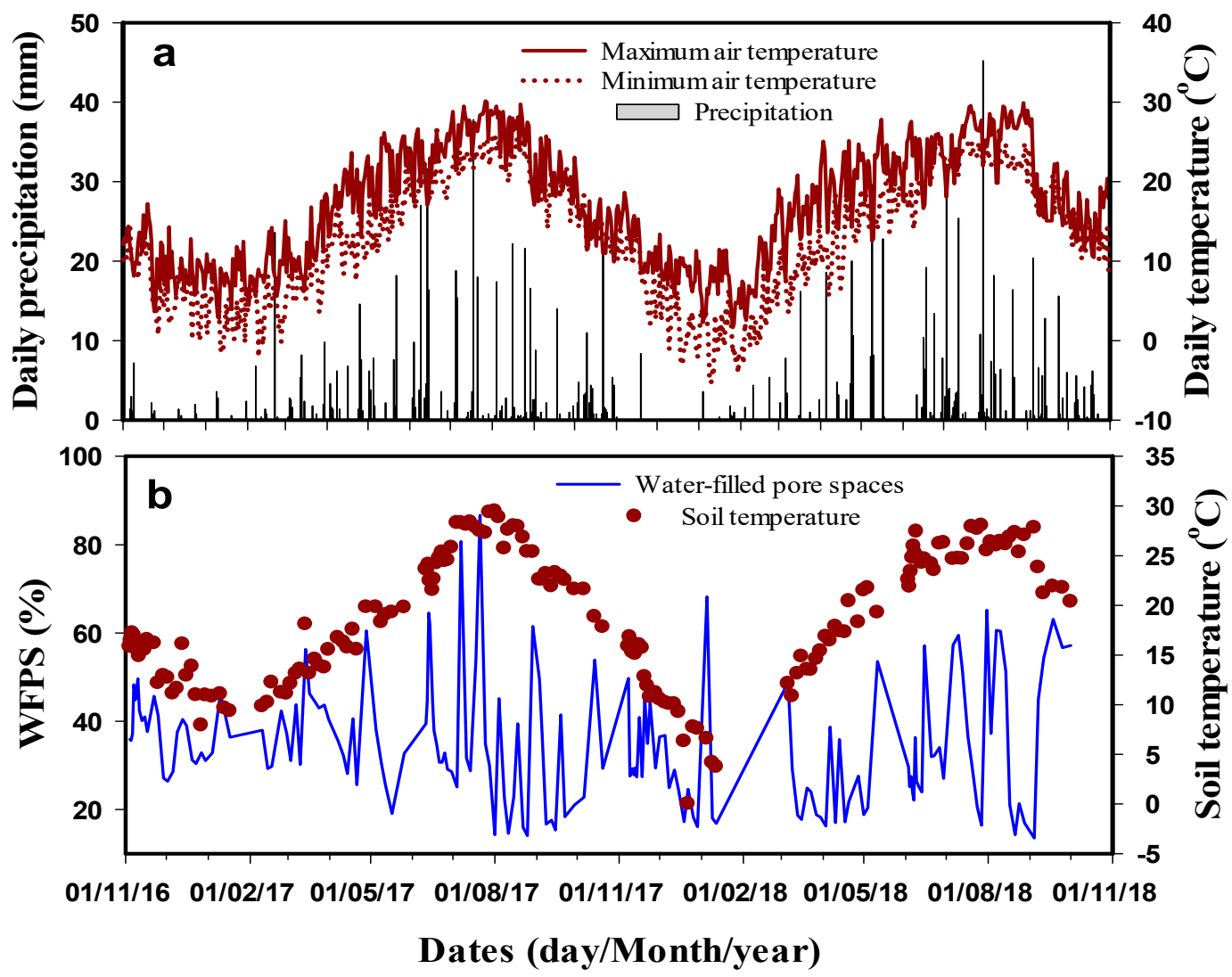

Figure 1. (a) Daily precipitation ( $\mathrm{mm})$, daily maximum and minimum air temperature $\left({ }^{\circ} \mathrm{C}\right)$ and (b) seasonal variations in mean soil water-filled pore space (WFPS) and mean soil temperature (topsoil at $5 \mathrm{~cm}$ ) in the wheat-maize rotations for the four treatments over the two-year period from 2016-2018.

For the winter wheat season, the mean cumulative $\mathrm{CH}_{4}$ fluxes among the four treatments were $-1.54 \mathrm{~kg} \cdot \mathrm{C} \cdot \mathrm{ha}^{-1}$ for $\mathrm{CK},-1.77 \mathrm{~kg} \cdot \mathrm{C} \cdot \mathrm{ha}^{-1}$ for NPK, $-1.75 \mathrm{~kg} \cdot \mathrm{C} \cdot \mathrm{ha}^{-1}$ for OMNPK, and $-2.02 \mathrm{~kg} \cdot \mathrm{C} \cdot \mathrm{ha}^{-1}$ for CRNPK (Table 1). The seasonal mean cumulative $\mathrm{CH}_{4}$ fluxes for $\mathrm{CK}$ were significantly greater than those of the other treatments $(p<0.05)$, while NPK and OMNPK were not significantly different from each other. CRNPK showed the smallest significant mean cumulative $\mathrm{CH}_{4}$ flux $(p>0.05)($ Table 1). Comparatively, for the summer maize season, the mean cumulative $\mathrm{CH}_{4}$ fluxes were $-0.84 \mathrm{~kg} \mathrm{C}$ $\mathrm{ha}^{-1}$ for CK, $-0.99 \mathrm{~kg} \cdot \mathrm{C} \cdot \mathrm{ha}^{-1}$ for NPK, $-0.82 \mathrm{~kg} \cdot \mathrm{C} \cdot \mathrm{ha}^{-1}$ for OMNPK, and $-0.78 \mathrm{~kg} \cdot \mathrm{C} \cdot \mathrm{ha}^{-1}$ for CRNPK (Table 1). The mean cumulative $\mathrm{CH}_{4}$ fluxes for the CK, OMNPK, and CRNPK treatments showed no significant differences from each other $(p<0.05)$, while the NPK treatment had the smallest significant mean cumulative $\mathrm{CH}_{4}$ flux for the maize season (Table 1). Moreover, the annual mean cumulative $\mathrm{CH}_{4}$ fluxes were $-2.60 \mathrm{~kg} \cdot \mathrm{C} \cdot \mathrm{ha}^{-1}$ for CK, $-2.97 \mathrm{~kg} \cdot \mathrm{C} \cdot \mathrm{ha}^{-1}$ for NPK, -2.97 for OMNPK, and $-2.93 \mathrm{~kg} \cdot \mathrm{C} \cdot \mathrm{ha}^{-1}$ for CRNPK (Table 1). The annual mean cumulative $\mathrm{CH}_{4}$ fluxes for $\mathrm{CK}$ were significantly greater than those of the other treatments $(p<0.05)$, which were not significantly different from each other $(p>0.05)$. Overall, the annual cumulative $\mathrm{CH}_{4}$ flux was significantly different among the four treatments in the order of CK > NPK > CRNPK > OMNPK in the 2016/2017 cropping year (Figure 3a), while different trends were observed in the $2017 / 2018$ cropping year, with the order of CK > OMNPK > CRNPK > NPK (Figure 3b). 


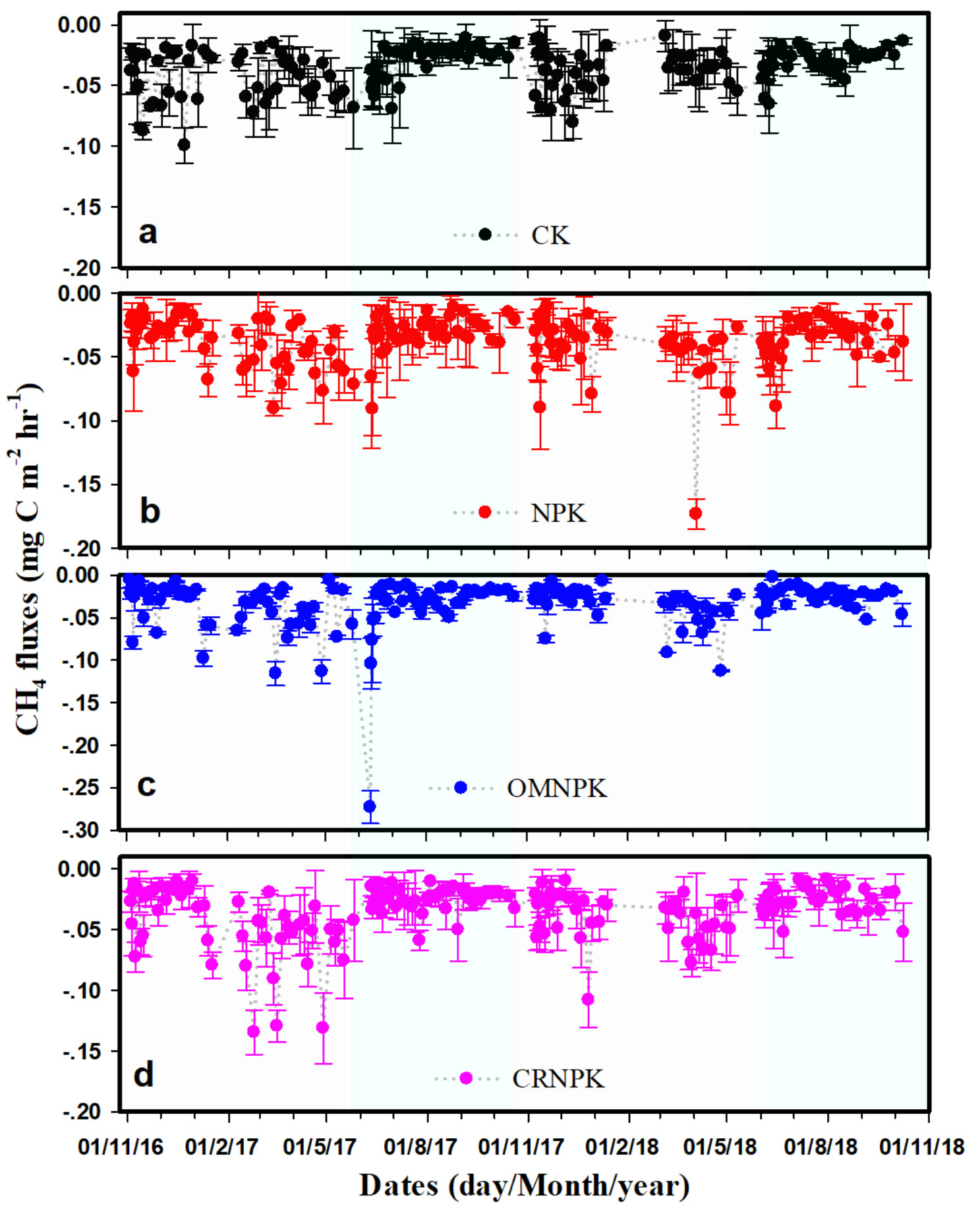

Figure 2. Seasonal variations in methane $\left(\mathrm{CH}_{4}\right)$ emissions in the wheat-maize rotations for $\mathrm{CK}=$ control $(\mathbf{a}), \mathrm{NPK}=$ mineral fertilizers $(\mathbf{b}), \mathrm{OMNPK}=$ pig slurry combined with mineral fertilizers (c) and CRNPK = crop residue combined with mineral fertilizers (d) treatments over the two-year period from 2016-2018. The vertical bars in the panels indicate the standard errors of spatial replicates $(n=3)$. 
Table 1. Seasonal and annual cumulative fluxes of methane $\left(\mathrm{CH}_{4}, \mathrm{~kg} \cdot \mathrm{C} \cdot \mathrm{ha}{ }^{-1}\right)$, nitrous oxide $\left(\mathrm{N}_{2} \mathrm{O}, \mathrm{kg} \cdot \mathrm{N} \cdot \mathrm{ha}{ }^{-1}\right)$, and direct emission factors $\left(\mathrm{EF} \mathrm{d}_{\mathrm{d}} \%\right)$ for the four treatments over the two-year period from 2016-2018.

\begin{tabular}{|c|c|c|c|c|c|c|c|c|c|c|}
\hline \multirow{2}{*}{ Year } & \multirow{2}{*}{ Treatments } & \multicolumn{3}{|c|}{ Wheat Season } & \multicolumn{3}{|c|}{ Maize Season } & \multicolumn{3}{|c|}{ Annual } \\
\hline & & $\mathrm{CH}_{4}$ & $\mathrm{~N}_{2} \mathrm{O}$ & $\mathbf{E F}_{\mathrm{d}}$ & $\mathrm{CH}_{4}$ & $\mathrm{~N}_{2} \mathrm{O}$ & $\mathrm{EF}_{\mathrm{d}}$ & $\mathrm{CH}_{4}$ & $\mathrm{~N}_{2} \mathrm{O}$ & $\mathrm{EF}_{\mathrm{d}}$ \\
\hline \multirow{4}{*}{ 2016-2017 } & CK & $-1.79 \pm 0.15 a$ & $0.19 \pm 0.01 d$ & - & $-0.83 \pm 0.02 \mathrm{a}$ & $0.19 \pm 0.06 c$ & - & $-2.81 \pm 0.15 a$ & $0.42 \pm 0.09 c$ & - \\
\hline & NPK & $-1.81 \pm 0.07 a$ & $0.73 \pm 0.04 b$ & 0.41 & $-0.93 \pm 0.04 a$ & $0.69 \pm 0.05 b$ & 0.34 & $-2.98 \pm 0.05 \mathrm{ab}$ & $1.48 \pm 0.08 b$ & 0.38 \\
\hline & OMNPK & $-2.05 \pm 0.31 \mathrm{a}$ & $0.62 \pm 0.02 c$ & 0.33 & $-0.89 \pm 0.03 a$ & $3.65 \pm 0.02 a$ & 2.31 & $-3.52 \pm 0.08 c$ & $4.76 \pm 0.04 a$ & 1.55 \\
\hline & CRNPK & $-2.38 \pm 0.04 b$ & $0.83 \pm 0.05 a$ & 0.49 & $-0.79 \pm 0.03 a$ & $0.81 \pm 0.09 b$ & 0.42 & $-3.27 \pm 0.06 b c$ & $1.77 \pm 0.14 b$ & 0.48 \\
\hline \multirow{4}{*}{ 2017-2018 } & CK & $-1.29 \pm 0.10 \mathrm{a}$ & $0.19 \pm 0.02 d$ & - & $-0.84 \pm 0.02 \mathrm{a}$ & $0.23 \pm 0.02 \mathrm{~d}$ & - & $-2.37 \pm 0.08 \mathrm{a}$ & $0.46 \pm 0.03 d$ & - \\
\hline & NPK & $-1.74 \pm 0.06 b$ & $0.59 \pm 0.04 b$ & 0.31 & $-1.05 \pm 0.05 b$ & $0.64 \pm 0.05 c$ & 0.27 & $-2.96 \pm 0.09 b$ & $1.33 \pm 0.09 c$ & 0.31 \\
\hline & OMNPK & $-1.45 \pm 0.07 \mathrm{ab}$ & $0.50 \pm 0.01 \mathrm{c}$ & 0.24 & $-0.75 \pm 0.01 \mathrm{a}$ & $2.92 \pm 0.01 \mathrm{a}$ & 1.79 & $-2.42 \pm 0.04 a$ & $4.40 \pm 0.02 a$ & 1.41 \\
\hline & CRNPK & $-1.66 \pm 0.11 b$ & $0.83 \pm 0.02 a$ & 0.50 & $-0.78 \pm 0.02 \mathrm{a}$ & $0.87 \pm 0.05 b$ & 0.42 & $-2.58 \pm 0.13 a$ & $1.82 \pm 0.02 b$ & 0.49 \\
\hline \multirow{4}{*}{ Mean (2016-2018) } & CK & $-1.54 \pm 0.07 a$ & $0.19 \pm 0.01 \mathrm{~d}$ & - & $-0.84 \pm 0.01 \mathrm{a}$ & $0.21 \pm 0.04 \mathrm{~d}$ & - & $-2.60 \pm 0.06 a$ & $0.44 \pm 0.05 d$ & - \\
\hline & NPK & $-1.77 \pm 0.01 b$ & $0.66 \pm 0.04 b$ & 0.36 & $-0.99 \pm 0.05 b$ & $0.67 \pm 0.04 c$ & 0.30 & $-2.97 \pm 0.06 b$ & $1.40 \pm 0.07 \mathrm{c}$ & 0.34 \\
\hline & OMNPK & $-1.75 \pm 0.05 b$ & $0.56 \pm 0.00 c$ & 0.28 & $-0.82 \pm 0.02 \mathrm{a}$ & $3.28 \pm 0.02 a$ & 2.05 & $-2.97 \pm 0.04 b$ & $4.58 \pm 0.01 \mathrm{a}$ & 1.48 \\
\hline & CRNPK & $-2.02 \pm 0.04 c$ & $0.83 \pm 0.02 a$ & 0.50 & $-0.78 \pm 0.03 a$ & $0.84 \pm 0.06 b$ & 0.42 & $-2.93 \pm 0.06 b$ & $1.80 \pm 0.07 \mathrm{~b}$ & 0.49 \\
\hline
\end{tabular}

Mean \pm SE: Means in columns followed by different lower case letter are significantly different (least significant difference (LSD), $p<0.05)$ and means followed by the same lower case letter are not significantly different (LSD, $p>0.05$ ). No amendment as control (CK), mineral fertilizers (NPK), pig slurry combined with mineral fertilizers (OMNPK), and crop residue combined with mineral fertilizers (CRNPK). Note: The $\mathrm{CH}_{4}$ and $\mathrm{N}_{2} \mathrm{O}$ fluxes for winter wheat cropping season (159 days) or summer maize cropping season (104 days) are expressed as $\mathrm{kg} \cdot \mathrm{C} \cdot \mathrm{ha}^{-1} \cdot \mathrm{season}^{-1}$ or $\mathrm{kg} \cdot \mathrm{N} \cdot \mathrm{ha}^{-1} \cdot \mathrm{season}^{-1}$, while the annual cumulative is expressed in $\mathrm{kg} \cdot \mathrm{C} \cdot \mathrm{ha}^{-1} \cdot \mathrm{yr}^{-1} \mathrm{or} \mathrm{kg} \cdot \mathrm{N} \cdot \mathrm{ha}^{-1} \cdot \mathrm{yr}^{-1}$. 

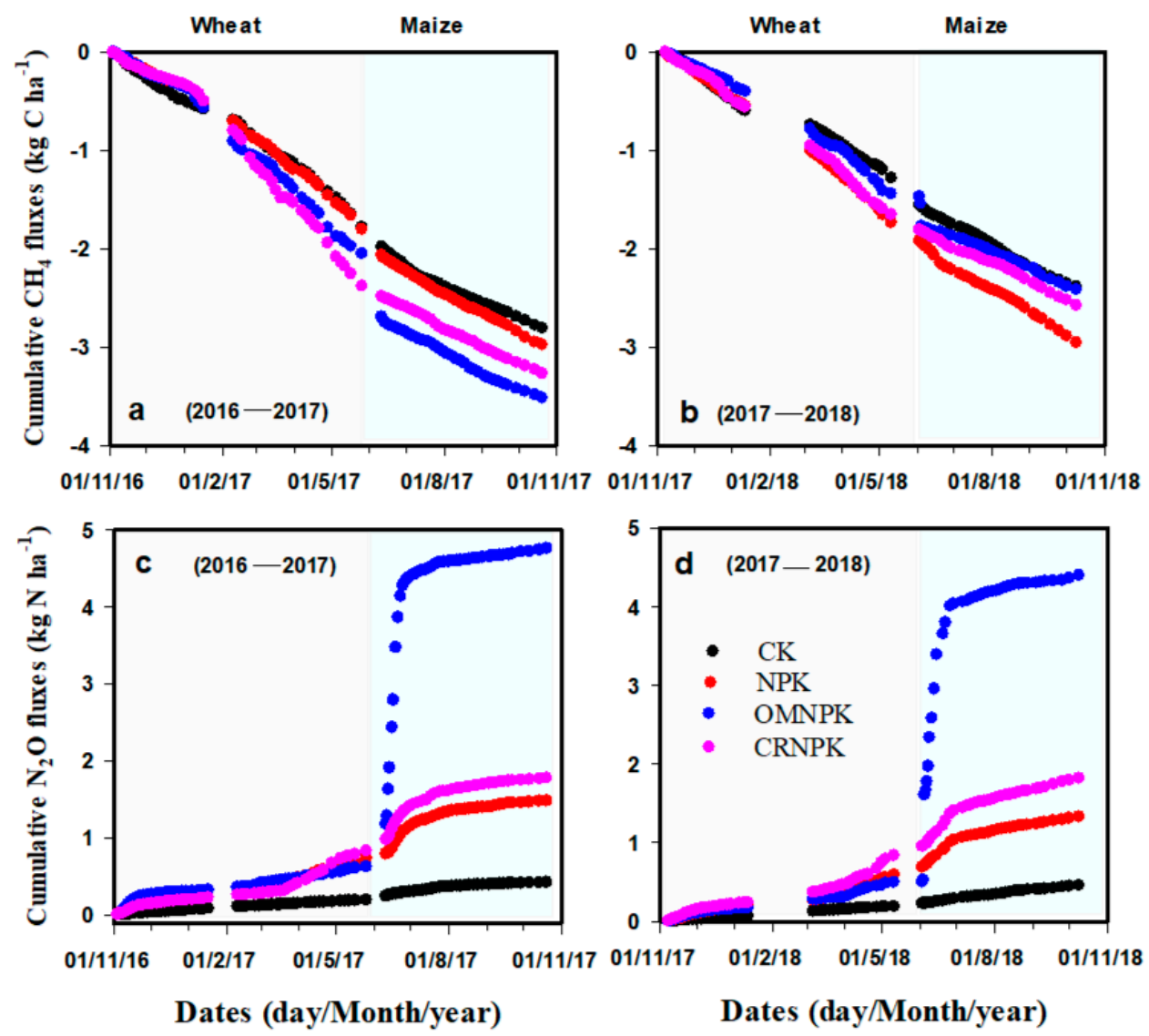

Figure 3. Seasonal and annual cumulative $\mathrm{CH}_{4}$ fluxes $(\mathbf{a}, \mathbf{b})$ and cumulative $\mathrm{N}_{2} \mathrm{O}$ fluxes $(\mathbf{c}, \mathbf{d})$ in the wheat-maize rotations for the four treatments over the two-year period from 2016-2018. Each colored circle point in the panels indicates the mean for measured data for three spatial replicates $(n=3)$ with error bars not shown.

\section{3. $\mathrm{N}_{2} \mathrm{O}$ Emissions}

This study found that $\mathrm{N}_{2} \mathrm{O}$ flux during the winter wheat season was lower than that during the summer maize season (Figure 4). Higher $\mathrm{N}_{2} \mathrm{O}$ emissions were measured in the initial two weeks after the various amendments were applied in both the winter wheat and summer maize seasons. During the winter wheat season, the $\mathrm{N}_{2} \mathrm{O}$ emissions ranged from 1.6 to $6.6 \mu \mathrm{g} \cdot \mathrm{N} \cdot \mathrm{m}^{-2} \cdot \mathrm{hr}^{-1}$ in the 2016/2017 cropping season and from 1.4 to $7.2 \mu \mathrm{g} \cdot \mathrm{N} \cdot \mathrm{m}^{-2} \cdot \mathrm{hr}^{-1}$ in the 2017/2018 cropping season for CK (Figure 4a); from 2.7 to $50.7 \mu \mathrm{g} \cdot \mathrm{N} \cdot \mathrm{m}^{-2} \cdot \mathrm{hr}^{-1}$ in the $2016 / 2017$ cropping season and from 3.4 to $45.0 \mu \mathrm{g} \cdot \mathrm{N} \cdot \mathrm{m}^{-2} \cdot \mathrm{hr}^{-1}$ in the 2017/2018 cropping season for NPK (Figure 4b); from 2.3 to $104.3 \mu \mathrm{g} \cdot \mathrm{N} \cdot \mathrm{m}^{-2} \cdot \mathrm{hr}^{-1}$ in the 2016/2017 cropping season and from 1.8 to $47.8 \mu \mathrm{g} \cdot \mathrm{N} \cdot \mathrm{m}^{-2} \cdot \mathrm{hr}^{-1}$ in the 2017/2018 cropping season for OMNPK (Figure 4c); and from 3.1 to $62.7 \mu \mathrm{g} \cdot \mathrm{N} \cdot \mathrm{m}^{-2} \cdot \mathrm{hr}^{-1}$ in the 2016/2017 cropping season and from 2.8 to $96.6 \mu \mathrm{g} \cdot \mathrm{N} \cdot \mathrm{m}^{-2} \cdot \mathrm{hr}^{-1}$ in the $2017 / 2018$ cropping season for CRNPK (Figure $4 \mathrm{~d}$ ). The highest $\mathrm{N}_{2} \mathrm{O}$ flux pulse event during the winter wheat season occurred in the OMNPK treatment in the 2016/2017 cropping season and in CRNPK treatment in the 2017/2018 cropping season.

Conversely, the $\mathrm{N}_{2} \mathrm{O}$ emissions for the summer maize season ranged from 1.0 to $25.0 \mu \mathrm{g} \cdot \mathrm{N} \cdot \mathrm{m}^{-2} \cdot \mathrm{hr}^{-1}$ in the 2017 cropping season and from 2.2 to $22.6 \mu \mathrm{g} \cdot \mathrm{N} \cdot \mathrm{m}^{-2} \cdot \mathrm{hr}^{-1}$ in the 2018 cropping season for CK (Figure 4a); from 1.0 to $175.4 \mu \mathrm{g} \cdot \mathrm{N} \cdot \mathrm{m}^{-2} \cdot \mathrm{hr}^{-1}$ in the 2017 cropping season and from 3.4 to $106.7 \mu \mathrm{g} \cdot \mathrm{N} \cdot \mathrm{m}^{-2} \cdot \mathrm{hr}^{-1}$ in the 2018 cropping season for NPK (Figure $4 \mathrm{~b}$ ); from 1.9 to $1492.1 \mu \mathrm{g} \cdot \mathrm{N} \cdot \mathrm{m}^{-2} \cdot \mathrm{hr}^{-1}$ in the 2017 cropping season and from 2.6 to $1545.4 \mu \mathrm{g} \cdot \mathrm{N} \cdot \mathrm{m}^{-2} \cdot \mathrm{hr}^{-1}$ in the $2018 \mathrm{cropping}$ season for OMNPK (Figure 4c); and from 1.5 to $195.7 \mu \mathrm{g} \cdot \mathrm{N} \cdot \mathrm{m}^{-2} \cdot \mathrm{hr}^{-1}$ in the 2017 cropping season and from 7.5 to $138.9 \mu \mathrm{g} \cdot \mathrm{N} \cdot \mathrm{m}^{-2} \cdot \mathrm{hr}^{-1}$ in the 2018 cropping season for CRNPK (Figure $4 \mathrm{~d}$ ). For the amendment 
treatments, the highest $\mathrm{N}_{2} \mathrm{O}$ emission pulse events during the summer maize season both occurred in the OMNPK treatment, while the lowest significant $\mathrm{N}_{2} \mathrm{O}$ emissions occurred in the NPK treatment in the 2017 and 2018 cropping seasons. Table S1 (Supplementary Materials) provides the mean seasonal and annual $\mathrm{N}_{2} \mathrm{O}$ emission variations.

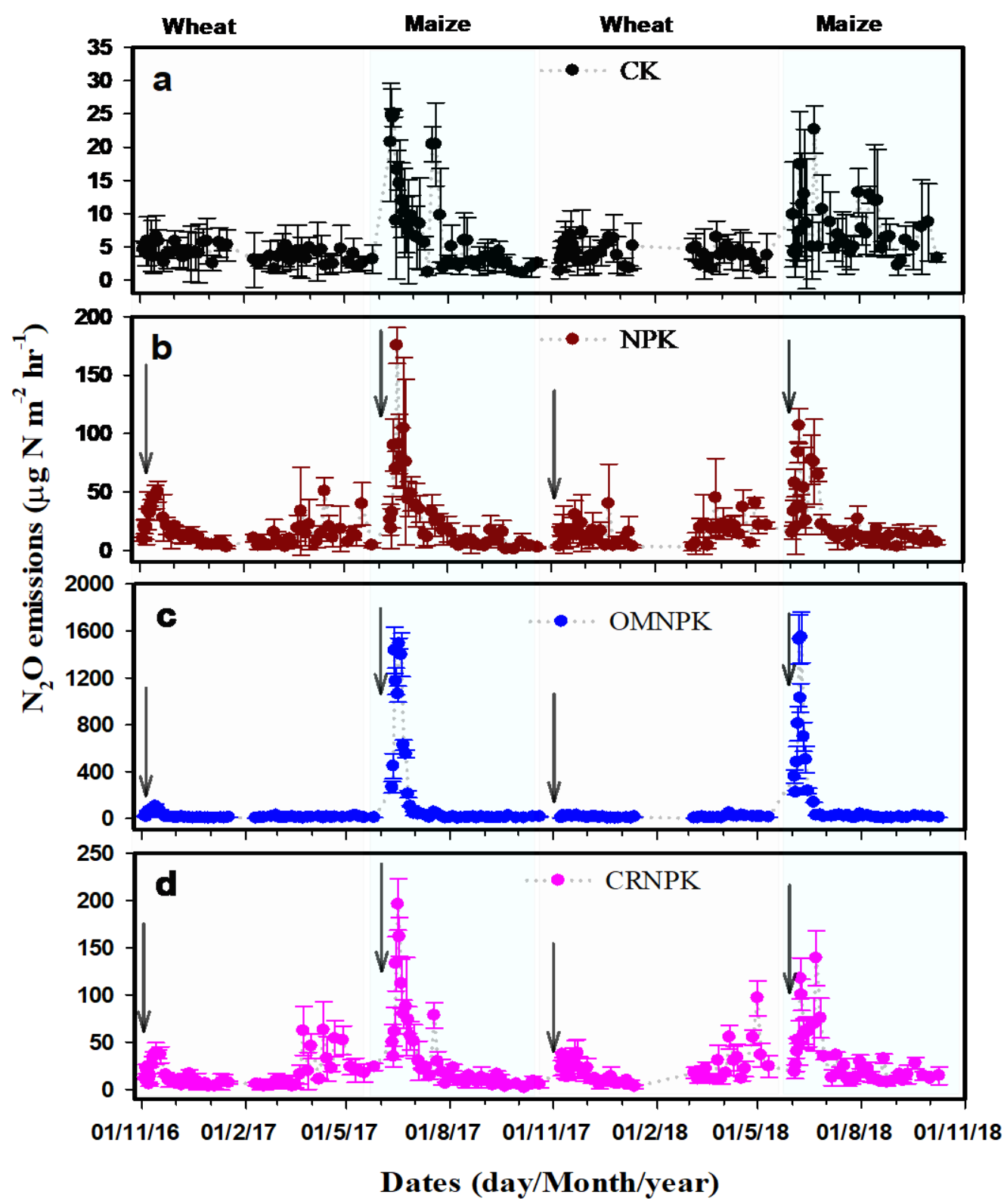

Figure 4. Seasonal variations in $\mathrm{N}_{2} \mathrm{O}$ emissions in the wheat-maize rotations for rotations for $\mathrm{CK}=$ control (a), NPK = mineral fertilizers $(\mathbf{b}), \mathrm{OMNPK}=$ pig slurry combined with mineral fertilizers (c) and CRNPK = crop residue combined with mineral fertilizers (d) treatments over the two-year period from 2016-2018. The vertical bars in the panels indicate the standard errors of spatial replicates $(n=3)$. The downward arrows indicate the date of different amendment applications.

Moreover, the mean cumulative $\mathrm{N}_{2} \mathrm{O}$ fluxes from all four treatments during the winter wheat season were $0.19 \mathrm{~kg} \cdot \mathrm{N} \cdot \mathrm{ha}^{-1}$ for CK, $0.66 \mathrm{~kg} \cdot \mathrm{N} \cdot \mathrm{ha}^{-1}$ for NPK, $0.56 \mathrm{~kg} \cdot \mathrm{N} \cdot \mathrm{ha}^{-1}$ for OMNPK, and $0.83 \mathrm{~kg} \cdot \mathrm{N} \cdot \mathrm{ha}^{-1}$ for CRNPK (Table 1). During the winter wheat season, the mean cumulative $\mathrm{N}_{2} \mathrm{O}$ flux for CRNPK was significantly higher than that in the other treatments, which significantly differed from each other $(p<0.05)$. The mean $\mathrm{EF}_{\mathrm{d}} \%$ (i.e., the emission factor) values ranged from $0.28-0.50 \%$ (i.e., below $1.0 \%$ ) (Table 1) during the winter wheat season. 
Comparatively, the mean cumulative $\mathrm{N}_{2} \mathrm{O}$ fluxes from all four treatments during the summer maize season were $0.21 \mathrm{~kg} \cdot \mathrm{N} \cdot \mathrm{ha}^{-1}$ for CK, $0.67 \mathrm{~kg} \cdot \mathrm{N} \cdot \mathrm{ha}^{-1}$ for NPK, $3.28 \mathrm{~kg} \cdot \mathrm{N} \cdot \mathrm{ha}^{-1}$ for OMNPK, and $0.84 \mathrm{~kg} \cdot \mathrm{N} \cdot \mathrm{ha}^{-1}$ for CRNPK (Table 1). The mean cumulative $\mathrm{N}_{2} \mathrm{O}$ flux for the summer maize season differed significantly among the four treatments $(p<0.05)$. The OMNPK treatment had a significantly higher $\mathrm{N}_{2} \mathrm{O}$ flux (i.e., approximately two times higher) than the other treatments in both 2017 and 2018 (Table 1). Moreover, the mean $\mathrm{EF}_{\mathrm{d}}(\%)$ values, ranging from $0.42-2.05 \%$, were higher during the summer maize season (Table 1).

Furthermore, the annual mean cumulative $\mathrm{N}_{2} \mathrm{O}$ fluxes throughout the two-year experimental period for all four treatments were $0.44 \mathrm{~kg} \cdot \mathrm{N} \cdot \mathrm{ha}^{-1}$ for $\mathrm{CK}, 1.40 \mathrm{~kg} \cdot \mathrm{N} \cdot \mathrm{ha}^{-1}$ for NPK, $4.58 \mathrm{~kg} \cdot \mathrm{N} \cdot \mathrm{ha}{ }^{-1}$ for OMNPK, and $1.80 \mathrm{~kg} \cdot \mathrm{N} \cdot \mathrm{ha}^{-1}$ for CRNPK (Table 1). The annual mean cumulative $\mathrm{N}_{2} \mathrm{O}$ flux for OMNPK was significantly greater than that in the other treatments, followed by the CRNPK and NPK treatments, which differed significantly from each other $(p<0.05)$. The mean annual $\mathrm{EF}_{\mathrm{d}}(\%)$ values exhibited trends similar to those of the mean seasonal $\mathrm{EF}_{\mathrm{d}}(\%)$, ranging from $0.49-1.48 \%$, with slight differences observed between the two-year experimental periods. Overall, the annual cumulative $\mathrm{N}_{2} \mathrm{O}$ flux was significantly different among the four treatments in the order of OMNPK $>$ CRNPK $>$ NPK $>$ CK in the 2016/2017 cropping year (Figure 3c), with similar trends observed in the 2017/2018 cropping year (Figure 3d). The OMNPK treatment emitted more $\mathrm{N}_{2} \mathrm{O}$ than the CRNPK and NPK treatments, contributing approximately $56 \%$ of the total mean annual $\mathrm{N}_{2} \mathrm{O}$ flux. Thus, the OMNPK treatment was the greatest $\mathrm{N}_{2} \mathrm{O}$ source.

\subsection{Changes in Soil Substrates}

The ammonia nitrogen $\left(\mathrm{NH}_{4}{ }^{+}-\mathrm{N}\right)$, nitrate nitrogen $\left(\mathrm{NO}_{3}{ }^{-}-\mathrm{N}\right)$, and dissolved organic carbon (DOC) in the soil substrates under four treatments in both the winter wheat and summer maize seasons are shown in Figure 5. During the winter wheat season, the $\mathrm{NH}_{4}{ }^{+} \mathrm{N}$ ranged from 0.1 to $2.9 \mathrm{mg} \cdot \mathrm{N} \cdot \mathrm{kg}^{-1}$ in the 2016/2017 cropping season and from 0.3 to $3.3 \mathrm{mg} \cdot \mathrm{N} \cdot \mathrm{kg}^{-1}$ in the $2017 / 2018$ cropping season for CK (Figure 5a); from 0.6 to $13.0 \mathrm{mg} \cdot \mathrm{N} \cdot \mathrm{kg}^{-1}$ in the 2016/2017 cropping season and from 0.7 to $10.1 \mathrm{mg} \cdot \mathrm{N} \cdot \mathrm{kg}^{-1}$ in the $2017 / 2018$ cropping season for NPK (Figure 5a); from 0.5 to $12.6 \mathrm{mg} \cdot \mathrm{N} \cdot \mathrm{kg}^{-1}$ in the $2016 / 2017$ cropping season and from 0.8 to $8.8 \mathrm{mg} \cdot \mathrm{N} \cdot \mathrm{kg}^{-1}$ in the $2017 / 2018$ cropping season for OMNPK (Figure 5a); and from 0.8 to $11.5 \mathrm{mg} \cdot \mathrm{N} \cdot \mathrm{kg}^{-1}$ in the 2016/2017 cropping season and from 0.9 to $10.5 \mathrm{mg} \cdot \mathrm{N} \cdot \mathrm{kg}^{-1}$ in the $2017 / 2018$ cropping season for CRNPK (Figure 5a). We observed a significantly higher soil $\mathrm{NH}_{4}{ }^{+}-\mathrm{N}$ content in the NPK treatment in 2016/2017, while the NPK and CRNPK treatments showed similar soil $\mathrm{NH}_{4}{ }^{+}-\mathrm{N}$ contents in the 2017/2018 wheat cropping season (Figure 5a).

During the summer maize season, a much lower range of $\mathrm{NH}_{4}{ }^{+}-\mathrm{N}$ contents was observed, varying from 0.1 to $2.3 \mathrm{mg} \cdot \mathrm{N} \cdot \mathrm{kg}^{-1}$ in the 2017 cropping season and from 0.2 to $3.8 \mathrm{mg} \cdot \mathrm{N} \cdot \mathrm{kg}^{-1}$ in the 2018 cropping season for CK (Figure 5a); from 0.1 to $2.8 \mathrm{mg} \cdot \mathrm{N} \cdot \mathrm{kg}^{-1}$ in the 2017 cropping season and from 0.1 to $4.4 \mathrm{mg} \cdot \mathrm{N} \cdot \mathrm{kg}^{-1}$ in the 2018 cropping season for NPK (Figure 5a); from 0.1 to $2.5 \mathrm{mg} \cdot \mathrm{N} \cdot \mathrm{kg}^{-1}$ in the 2017 cropping season and from 0.2 to $4.9 \mathrm{mg} \cdot \mathrm{N} \cdot \mathrm{kg}^{-1}$ in the 2018 cropping season for OMNPK (Figure 5a); and from 0.6 to $2.8 \mathrm{mg} \cdot \mathrm{N} \cdot \mathrm{kg}^{-1}$ in the 2017 cropping season and from 0.1 to $6.2 \mathrm{mg} \cdot \mathrm{N} \cdot \mathrm{kg}^{-1}$ in the 2018 cropping season for CRNPK (Figure 5a). We observed the highest $\mathrm{NH}_{4}{ }^{+}-\mathrm{N}$ content in the NPK treatment in the 2017 cropping season and in the CRNPK treatment in the 2018 cropping season. Compared to that in the summer maize season, the soil $\mathrm{NH}_{4}{ }^{+}-\mathrm{N}$ content in the winter wheat season was higher.

Similarly, the soil $\mathrm{NO}_{3}{ }^{-}-\mathrm{N}$ content during the winter wheat season ranged from 0.7 to $18.3 \mathrm{mg} \cdot \mathrm{N} \cdot \mathrm{kg}^{-1}$ in the $2016 / 2017$ cropping season and from 3.5 to $41.8 \mathrm{mg} \cdot \mathrm{N} \cdot \mathrm{kg}^{-1}$ in the $2017 / 2018$ cropping season for CK (Figure 5b); from 3.9 to $140.4 \mathrm{mg} \cdot \mathrm{N} \cdot \mathrm{kg}^{-1}$ in the $2016 / 2017$ cropping season and from 12.4 to $122.3 \mathrm{mg} \cdot \mathrm{N} \cdot \mathrm{kg}^{-1}$ in the 2017/2018 cropping season for NPK (Figure $5 \mathrm{~b}$ ); from 2.6 to $113.0 \mathrm{mg} \cdot \mathrm{N} \cdot \mathrm{kg}^{-1}$ in the $2016 / 2017$ cropping season and from 1.8 to $89.5 \mathrm{mg} \cdot \mathrm{N} \cdot \mathrm{kg}^{-1}$ in the $2017 / 2018$ cropping season for OMNPK (Figure $5 \mathrm{~b}$ ); and from 2.5 to $86.5 \mathrm{mg} \cdot \mathrm{N} \cdot \mathrm{kg}^{-1}$ in the $2016 / 2017$ cropping season and from 1.8 to $155.9 \mathrm{mg} \cdot \mathrm{N} \cdot \mathrm{kg}^{-1}$ in the 2017/2018 cropping season for CRNPK (Figure 5b). The NPK and CRNPK treatments exhibited significantly higher soil $\mathrm{NO}_{3}{ }^{-}-\mathrm{N}$ contents in 2016/2017 and 2017/2018 cropping seasons, respectively. 

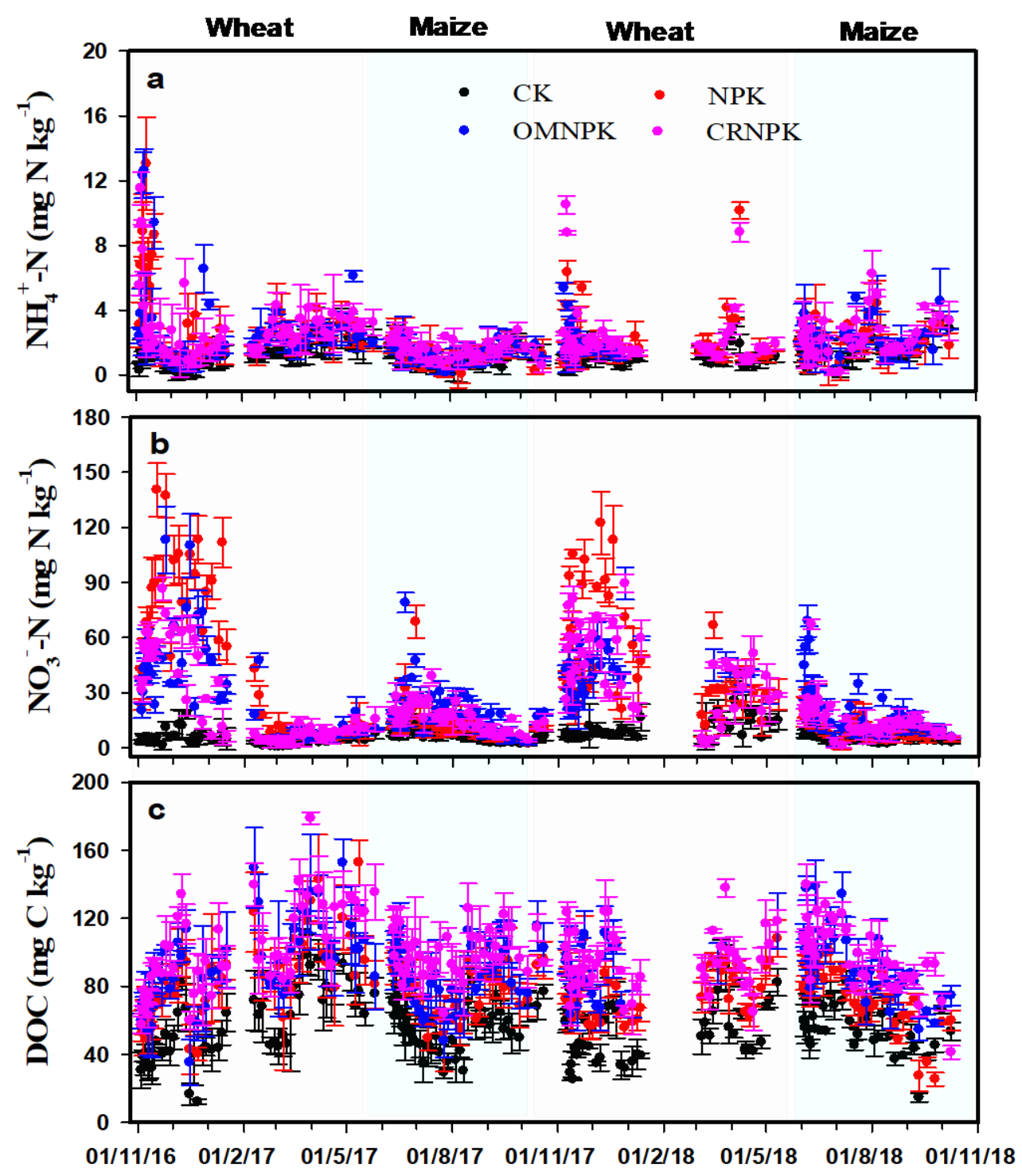

Dates (day/Month/year)

Figure 5. Seasonal variations of soil ammonia nitrogen $\left(\mathrm{NH}_{4}{ }^{-}-\mathrm{N}\right)(\mathbf{a})$, soil nitrate nitrogen $\left(\mathrm{NO}_{3}{ }^{-}-\mathrm{N}\right)(\mathbf{b})$, and dissolved organic carbon (DOC) (c) contents of topsoil $(0-15 \mathrm{~cm})$ of wheat-maize rotations for the four treatments over the two-year period from 2016-2018. The vertical bars indicate the standard errors of spatial replicates $(n=3)$.

Conversely, the soil $\mathrm{NO}_{3}{ }^{-}-\mathrm{N}$ content during the summer maize season ranged from 2.2 to $15.5 \mathrm{mg} \cdot \mathrm{N} \cdot \mathrm{kg}^{-1}$ in the 2017 cropping season and from 1.0 to $16.1 \mathrm{mg} \cdot \mathrm{N} \cdot \mathrm{kg}^{-1}$ in the 2018 cropping season for CK (Figure 5b); from 2.3 to $68.6 \mathrm{mg} \cdot \mathrm{N} \cdot \mathrm{kg}^{-1}$ in the 2017 cropping season and from 0.6 to $34.1 \mathrm{mg} \cdot \mathrm{N} \cdot \mathrm{kg}^{-1}$ in the 2018 cropping season for NPK (Figure 5b); from 2.8 to $79.0 \mathrm{mg} \cdot \mathrm{N} \cdot \mathrm{kg}^{-1}$ in the 2017 season and from 4.2 to $69.1 \mathrm{mg} \cdot \mathrm{N} \cdot \mathrm{kg}^{-1}$ in the 2018 cropping season for OMNPK (Figure 5b); and from 4.1 to $38.9 \mathrm{mg} \cdot \mathrm{N} \cdot \mathrm{kg}^{-1}$ in the 2017 cropping season and from 1.1 to $67.2 \mathrm{mg} \cdot \mathrm{N} \cdot \mathrm{kg}^{-1}$ in the 2018 cropping season for CRNPK (Figure 5b). We observed the highest $\mathrm{NO}_{3}{ }^{-}-\mathrm{N}$ content in the OMNPK treatment during the summer maize season in both 2017 and 2018. Compared to that in the summer maize season, the soil $\mathrm{NO}_{3}{ }^{-}-\mathrm{N}$ content in the winter wheat season was higher.

Furthermore, the soil dissolved organic carbon (DOC) content during the winter wheat season ranged from 12.1 to $98.7 \mathrm{mg} \cdot \mathrm{C} \cdot \mathrm{kg}^{-1}$ in the $2016 / 2017$ cropping season and from 25.3 to $92.1 \mathrm{mg} \cdot \mathrm{C} \cdot \mathrm{kg}^{-1}$ in the 2017/2018 cropping season for CK (Figure 5c); from 40.2 to $152.8 \mathrm{mg} \cdot \mathrm{C} \cdot \mathrm{kg}^{-1}$ in the 2016/2017 cropping season and from 55.8 to $108.3 \mathrm{mg} \cdot \mathrm{C} \cdot \mathrm{kg}^{-1}$ in the 2017/2018 cropping season for NPK (Figure 5c); 
from 35.3 to $152.5 \mathrm{mg} \cdot \mathrm{C} \cdot \mathrm{kg}^{-1}$ in the $2016 / 2017$ cropping season and from 63.5 to $137.9 \mathrm{mg} \cdot \mathrm{C} \cdot \mathrm{kg}^{-1}$ in the 2017/2018 cropping season for OMNPK (Figure 5c); and from 57.4 to $178.9 \mathrm{mg} \cdot \mathrm{C} \cdot \mathrm{kg}^{-1}$ in the 2016/2017 cropping season and from 64.9 to $137.9 \mathrm{mg} \cdot \mathrm{C} \cdot \mathrm{kg}^{-1}$ in the 2017/2018 cropping season for CRNPK (Figure 5c). The DOC content exhibited a similar pattern across all four treatments, and the highest soil DOC content was observed in the CRNPK treatment in 2016/2017, while the OMNPK and CRNPK treatments showed the highest soil DOC contents in the 2017/2018 cropping season.

Meanwhile, the soil DOC during the summer maize season ranged from 29.3 to $82.9 \mathrm{mg} \cdot \mathrm{C} \cdot \mathrm{kg}^{-1}$ in the 2017 cropping season and from 14.6 to $82.7 \mathrm{mg} \cdot \mathrm{C} \cdot \mathrm{kg}^{-1}$ in the 2018 cropping season for CK (Figure 5c); from 49.6 to $106.0 \mathrm{mg} \cdot \mathrm{C} \cdot \mathrm{kg}^{-1}$ in the 2017 cropping season and from 25.4 to $100.1 \mathrm{mg} \cdot \mathrm{C} \cdot \mathrm{kg}^{-1}$ in the 2018 cropping season for NPK (Figure 5c); from 48.0 to $115.5 \mathrm{mg} \cdot \mathrm{C} \cdot \mathrm{kg}^{-1}$ in the $2017 \mathrm{cropping}$ season and from 54.5 to $138.8 \mathrm{mg} \cdot \mathrm{C} \cdot \mathrm{kg}^{-1}$ in the 2018 cropping season for OMNPK (Figure 5c); and from 63.8 to $125.8 \mathrm{mg} \cdot \mathrm{C} \cdot \mathrm{kg}^{-1}$ in the 2017 cropping season and from 41.2 to $194.3 \mathrm{mg} \cdot \mathrm{C} \cdot \mathrm{kg}^{-1}$ in the 2018 cropping season for CRNPK (Figure 5c). The CRNPK treatment had the highest soil DOC content during the summer maize season in both the 2017 and 2018 cropping seasons. Table S2 (Supplementary Materials) provides the variation in mean seasonal and annual $\mathrm{NH}_{4}{ }^{+}-\mathrm{N}, \mathrm{NO}_{3}{ }^{-}-\mathrm{N}$, and $\mathrm{DOC}$ contents.

\subsection{Global Warming Potential (GWP)}

Table 2 provides the seasonal and annual GWP of $\mathrm{N}_{2} \mathrm{O}$ and $\mathrm{CH}_{4}$ emissions from all four treatments, including the mean GWP throughout the two-year wheat-maize rotational experimental period. Significant differences were observed between all four treatments in both cropping seasons and years $(p<0.05)$ as shown in Table 2. The mean GWP in the winter wheat season was $0.02 \mathrm{Mg} \mathrm{CO}_{2}$-eq.ha ${ }^{-1}$ for CK, $0.21 \mathrm{Mg} \mathrm{CO}_{2}$-eq.ha ${ }^{-1}$ for NPK, $0.17 \mathrm{Mg} \mathrm{CO}_{2}$-eq.ha ${ }^{-1}$ for OMNPK, and $0.27 \mathrm{Mg} \mathrm{CO}_{2}$-eq.ha ${ }^{-1}$ for CRNPK (Table 2). The mean GWP in the winter wheat season for the CRNPK treatment was significantly greater than those for the other treatments, which were significantly different from each other $(p<0.05)$. Moreover, the mean GWP in the summer maize season was $0.06 \mathrm{Mg} \mathrm{CO}_{2}$-eq.ha ${ }^{-1}$ for $\mathrm{CK}, 0.24 \mathrm{Mg} \mathrm{CO}_{2}$-eq.ha ${ }^{-1}$ for NPK, $1.34 \mathrm{Mg} \mathrm{CO}_{2}$-eq.ha ${ }^{-1}$ for OMNPK, and $0.32 \mathrm{Mg} \mathrm{CO}_{2}$-eq.ha ${ }^{-1}$ for CRNPK. In contrast to the pattern observed in the winter wheat season, the mean GWP in the summer maize season for the OMNPK treatment was significantly higher than that in the other treatments, which also significantly differed from each other $(p<0.05)$ (Table 2). During the summer maize season, the OMNPK treatment had a higher GWP in 2017 (compared to 2018), accounting for $71 \%$ and $65 \%$ of the total GWP, respectively.

Furthermore, the mean annual GWP was $0.08 \mathrm{Mg} \mathrm{CO}_{2}$-eq.ha ${ }^{-1}$ for $\mathrm{CK}, 0.47 \mathrm{Mg} \mathrm{CO}_{2}$-eq.ha ${ }^{-1}$ for NPK, $1.80 \mathrm{Mg} \mathrm{CO}_{2}$-eq.ha ${ }^{-1}$ for OMNPK, and $0.64 \mathrm{Mg} \mathrm{CO}_{2}$-eq.ha ${ }^{-1}$ for CRNPK (Table 2). The OMNPK treatment showed a significantly higher mean annual GWP than the other treatments, which was attributable to the high $\mathrm{N}_{2} \mathrm{O}$ emissions during the summer maize season in both years. The CRNPK treatment had the second highest annual GWP throughout the two-year experimental period, which differed significantly from those in the NPK and CK treatments (Table 2). Compared to that in the OMNPK and CRNPK treatments, the annual GWP in NPK was significantly lower in both years, which was attributed to the low $\mathrm{N}_{2} \mathrm{O}$ emissions and the smallest $\mathrm{CH}_{4}$ fluxes.

\subsection{Grain Yield}

Table 2 provides grain yields from the wheat-maize rotational system throughout the two-year experimental period. During the winter wheat season, the mean grain yields were $0.64 \mathrm{Mg}^{-\mathrm{ha}^{-1}}$ for CK, $2.93 \mathrm{Mg} \cdot \mathrm{ha}^{-1}$ for NPK, $3.50 \mathrm{Mg} \cdot \mathrm{ha}^{-1}$ for OMNPK, and 3.09 Mg.ha ${ }^{-1}$ for CRNPK (Table 2). The mean grain yields for wheat cropping seasons for OMNPK were significantly greater than those for the other treatments $(p<0.05)$, while the NPK and CRNPK treatments exhibited no significant differences in grain yield. 
Table 2. Seasonal and annual global warming potential of $\mathrm{CH}_{4}$ and $\mathrm{N}_{2} \mathrm{O}$ emissions $\left(\mathrm{GWP}, \mathrm{Mg} \mathrm{CO}_{2}\right.$-eq·ha ${ }^{-1}$ ), grain yield (Mg.ha-1 ), and yield-scaled global warming potential of $\mathrm{CH}_{4}$ and $\mathrm{N}_{2} \mathrm{O}$ emissions (yield-scaled GWP, $\mathrm{kg} \mathrm{CO}_{2}$-eq. $\mathrm{Mg}^{-1}$ gain) for the four treatments over the two-year period from $2016-2018$.

\begin{tabular}{|c|c|c|c|c|c|c|c|c|c|}
\hline \multirow[b]{2}{*}{ Year } & \multirow[b]{2}{*}{ Treatments } & \multicolumn{3}{|c|}{ Wheat Season } & \multicolumn{3}{|c|}{ Maize Season } & \multicolumn{2}{|c|}{ Annual } \\
\hline & & GWP & Yield & $\begin{array}{c}\text { Yield-Scaled } \\
\text { GWP }\end{array}$ & GWP & Yield & $\begin{array}{c}\text { Yield-Scaled } \\
\text { GWP }\end{array}$ & GWP & $\begin{array}{c}\text { Yield-Scaled } \\
\text { GWP }\end{array}$ \\
\hline \multirow{4}{*}{ 2016-2017 } & CK & $0.01 \pm 0.01 c$ & $0.73 \pm 0.13 c$ & $22.24 \pm 16.22 b$ & $0.05 \pm 0.02 c$ & $1.35 \pm 0.10 b$ & $34.07 \pm 16.86 b$ & $0.07 \pm 0.03 c$ & $33.20 \pm 14.48 c$ \\
\hline & NPK & $0.24 \pm 0.01 \mathrm{a}$ & $2.29 \pm 0.28 b$ & $107.82 \pm 21.65 a$ & $0.25 \pm 0.02 b$ & $4.22 \pm 0.33 a$ & $60.26 \pm 1.09 b$ & $0.50 \pm 0.03 b$ & $77.31 \pm 4.41 \mathrm{bc}$ \\
\hline & OMNPK & $0.18 \pm 0.01 b$ & $3.14 \pm 0.12 \mathrm{a}$ & $58.11 \pm 3.48 \mathrm{ab}$ & $1.49 \pm 0.01 a$ & $4.38 \pm 0.50 \mathrm{a}$ & $347.20 \pm 36.94 a$ & $1.85 \pm 0.01 \mathrm{a}$ & $249.41 \pm 21.66 a$ \\
\hline & CRNPK & $0.26 \pm 0.02 a$ & $2.51 \pm 0.12 b$ & $103.13 \pm 12.36 a$ & $0.31 \pm 0.04 b$ & $4.88 \pm 0.09 a$ & $63.64 \pm 8.85 b$ & $0.62 \pm 0.06 \mathrm{~b}$ & $83.86 \pm 9.80 \mathrm{~b}$ \\
\hline \multirow{3}{*}{ 2017-2018 } & CK & $0.03 \pm 0.01 \mathrm{c}$ & $0.55 \pm 0.06 b$ & $54.66 \pm 10.75 b$ & $0.07 \pm 0.01 d$ & $0.56 \pm 0.16 b$ & $134.20 \pm 32.72 b$ & $0.10 \pm 0.01 d$ & $98.04 \pm 24.85 b$ \\
\hline & NPK & $0.18 \pm 0.02 b$ & $3.56 \pm 0.21 \mathrm{a}$ & $51.08 \pm 5.98 b$ & $0.23 \pm 0.02 c$ & $5.14 \pm 0.49 a$ & $44.82 \pm 4.51 \mathrm{c}$ & $0.44 \pm 0.04 c$ & $51.42 \pm 5.55 c$ \\
\hline & CRNPK & $0.29 \pm 0.01 \mathrm{a}$ & $3.68 \pm 0.06 a$ & $77.65 \pm 2.50 \mathrm{a}$ & $0.33 \pm 0.02 b$ & $5.26 \pm 0.46 a$ & $63.88 \pm 3.44 c$ & $0.66 \pm 0.01 b$ & $74.29 \pm 4.08 b c$ \\
\hline \multirow{4}{*}{$\begin{array}{c}\text { Mean } \\
(2016-2018)\end{array}$} & CK & $0.02 \pm 0.01 \mathrm{~d}$ & $0.64 \pm 0.05 c$ & $38.45 \pm 12.04 c$ & $0.06 \pm 0.02 \mathrm{~d}$ & $0.96 \pm 0.13 b$ & $84.14 \pm 22.43 b$ & $0.08 \pm 0.02 \mathrm{~d}$ & $65.62 \pm 18.99 b$ \\
\hline & NPK & $0.21 \pm 0.02 b$ & $2.93 \pm 0.16 b$ & $79.45 \pm 13.08 \mathrm{ab}$ & $0.24 \pm 0.02 c$ & $4.68 \pm 0.39 a$ & $52.54 \pm 1.72 b$ & $0.47 \pm 0.03 c$ & $64.37 \pm 4.44 b$ \\
\hline & OMNPK & $0.17 \pm 0.00 c$ & $3.50 \pm 0.10 \mathrm{a}$ & $48.83 \pm 1.39 \mathrm{bc}$ & $1.34 \pm 0.01 \mathrm{a}$ & $4.83 \pm 0.13 a$ & $286.74 \pm 12.62 a$ & $1.80 \pm 0.00 \mathrm{a}$ & $220.19 \pm 8.19 a$ \\
\hline & CRNPK & $0.27 \pm 0.01 \mathrm{a}$ & $3.09 \pm 0.09 b$ & $90.39 \pm 6.16 a$ & $0.32 \pm 0.02 b$ & $5.07 \pm 0.19 a$ & $63.76 \pm 2.89 \mathrm{~b}$ & $0.64 \pm 0.03 b$ & $79.08 \pm 3.54 b$ \\
\hline
\end{tabular}

Mean \pm SE: Means in columns followed by different lower case letter are significantly different (least significant difference (LSD), $p<0.05)$ and means followed by the same lower case letter are not significantly different (LSD, $p>0.05$ ). No amendment as control (CK), mineral fertilizers (NPK), pig slurry combined with mineral fertilizers (OMNPK), and crop residues combined with mineral fertilizers (CRNPK). 
Conversely, throughout the summer maize season, the mean grain yields were $0.96 \mathrm{Mg} \cdot \mathrm{ha}^{-1}$

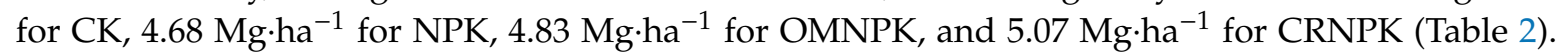
The mean maize grain yields for the NPK, OMNPK, and CRNPK treatments did not differ significantly $(p>0.05)$ in the summer maize cropping seasons. Moreover, over the two-year experimental period, the CRNPK treatment produced the highest annual maize grain yield, but it was not significantly different from the other amendment treatments $(p=0.58)$, indicating the higher productivity of summer maize compared to winter wheat. Furthermore, the maize grain yields for the OMNPK and CRNPK treatments increased by 5 and $16 \%$, respectively, in the winter wheat season and by 3-8\% in the summer maize season compared to those in the NPK treatment. These results indicated that combining organic amendments with mineral fertilizers can sustain wheat and maize grain yields.

\subsection{Yield-Scaled GWP}

Table 2 provides the seasonal and annual yield-scaled GWP during the winter wheat and summer maize seasons. The mean yield-scaled GWP during the winter wheat season for the CK, NPK, OMNPK, and CRNPK treatments was $38.45,79.45,48.83$, and $90.38 \mathrm{~kg} \cdot \mathrm{CO}_{2}$-eq.ha ${ }^{-1} \cdot \mathrm{Mg}^{-1}$ grain, respectively (Table 2). The NPK and CRNPK treatments exhibited the highest mean yield-scaled GWP values, but these values did not significantly differ in 2016/2017 (Table 2). With the low $\mathrm{N}_{2} \mathrm{O}$ emissions during the winter wheat season, we observed even lower and significantly different yield-scaled GWP values. During the summer maize season, the mean yield-scaled GWP for CK, NPK, OMNPK, and CRNPK was $84.14,52.54,286.74$, and $63.76 \mathrm{~kg} \cdot \mathrm{CO}_{2}$-eq $\cdot \mathrm{ha}^{-1} \cdot \mathrm{Mg}^{-1}$ grain, respectively (Table 2). The mean yield-scaled GWP for OMNPK was significantly higher than that in the other three treatments $(p<0.05)$, while those in the CK, NPK, and CRNPK treatments did not significantly differ from each other $(p>0.05)$. On the other hand, the $\mathrm{N}_{2} \mathrm{O}$ content of the OMNPK treatment was high, which resulted in higher yield-scaled GWP values in both the 2017 and 2018 cropping seasons. Interestingly, the control (CK, no amendment) exhibited similar annual yield-scaled GWP values as NPK and CRNPK in the 2017 cropping season, but significantly higher values than those in NPK and CRNPK in the 2018 cropping season (Table 2). This could be due to the decrease in grain yield and an increase in $\mathrm{CH}_{4}$ uptake in the CK treatment.

Moreover, the annual yield-scaled GWP values for CK, NPK, OMNPK, and CRNPK were $65.62,64.37,220.19$, and $79.08 \mathrm{~kg} \cdot \mathrm{CO}_{2}$-eq.ha ${ }^{-1} \cdot \mathrm{Mg}^{-1}$ grain, respectively (Table 2). The mean annual yield-scaled GWP for the OMNPK treatment was significantly higher than that for the other treatments throughout the two-year experimental period. This was due to the high $\mathrm{N}_{2} \mathrm{O}$ flux during the summer maize season. However, no significant differences were observed between the CK, NPK, and CRNPK treatments in terms of the mean annual yield-scaled GWP $(p<0.05)$.

\subsection{Relationships between $\mathrm{CH}_{4}$ Uptake and $\mathrm{N}_{2} \mathrm{O}$ Emissions, Environmental Factors, and Soil Substrates}

During the winter wheat season, we found a significant correlation between $\mathrm{CH}_{4}$ uptake and soil temperature (Figure 6a); however, no corresponding significant relationships were observed during the summer maize season (Figure 6c). Moreover, no significant correlations were observed between $\mathrm{CH}_{4}$ uptake and soil water-filled pore space (WFPS) during the winter wheat and summer maize seasons (Figure $6 \mathrm{~b}, \mathrm{~d}$ ). Additionally, no significant correlations were observed between $\mathrm{CH}_{4}$ uptake and $\mathrm{NH}_{4}{ }^{+}-\mathrm{N}$ content during the winter wheat season (Figure $7 \mathrm{a}$ ), while $\mathrm{CH}_{4}$ uptake and $\mathrm{NH}_{4}{ }^{+}-\mathrm{N}$ content were negatively correlated during the summer maize season (Figure $7 \mathrm{~d}$ ). Conversely, $\mathrm{CH}_{4}$ uptake and $\mathrm{NO}_{3}{ }^{-}-\mathrm{N}$ content were negatively correlated during both the winter wheat and summer maize seasons (Figure $7 \mathrm{~b}, \mathrm{e}$ ). Moreover, no significant correlations were observed between $\mathrm{CH}_{4}$ uptake and DOC content during the winter wheat season (Figure 7c), while we found that $\mathrm{CH}_{4}$ uptake and DOC content were negatively correlated during the summer maize season (Figure 7f). Our study revealed significant correlations between $\mathrm{N}_{2} \mathrm{O}$ emissions and soil temperature during the winter wheat and summer maize seasons $(p<0.0001)$ (Figure 8a). Conversely, no significant correlations were observed between $\mathrm{N}_{2} \mathrm{O}$ emissions and the WFPS of soil during the winter wheat season (Figure $8 b$ ); however, 
$\mathrm{N}_{2} \mathrm{O}$ emissions and the WFPS of soil were negatively correlated during the summer maize season (Figure 8d). Last, significant linear relationships were observed between $\mathrm{N}_{2} \mathrm{O}$ emissions and $\mathrm{NH}_{4}{ }^{+}-\mathrm{N}$, $\mathrm{NO}_{3}{ }^{-}-\mathrm{N}$, and DOC contents during both the winter wheat season and the summer maize season throughout the two-year experimental period $(p<0.0001)$ (Figure 9).
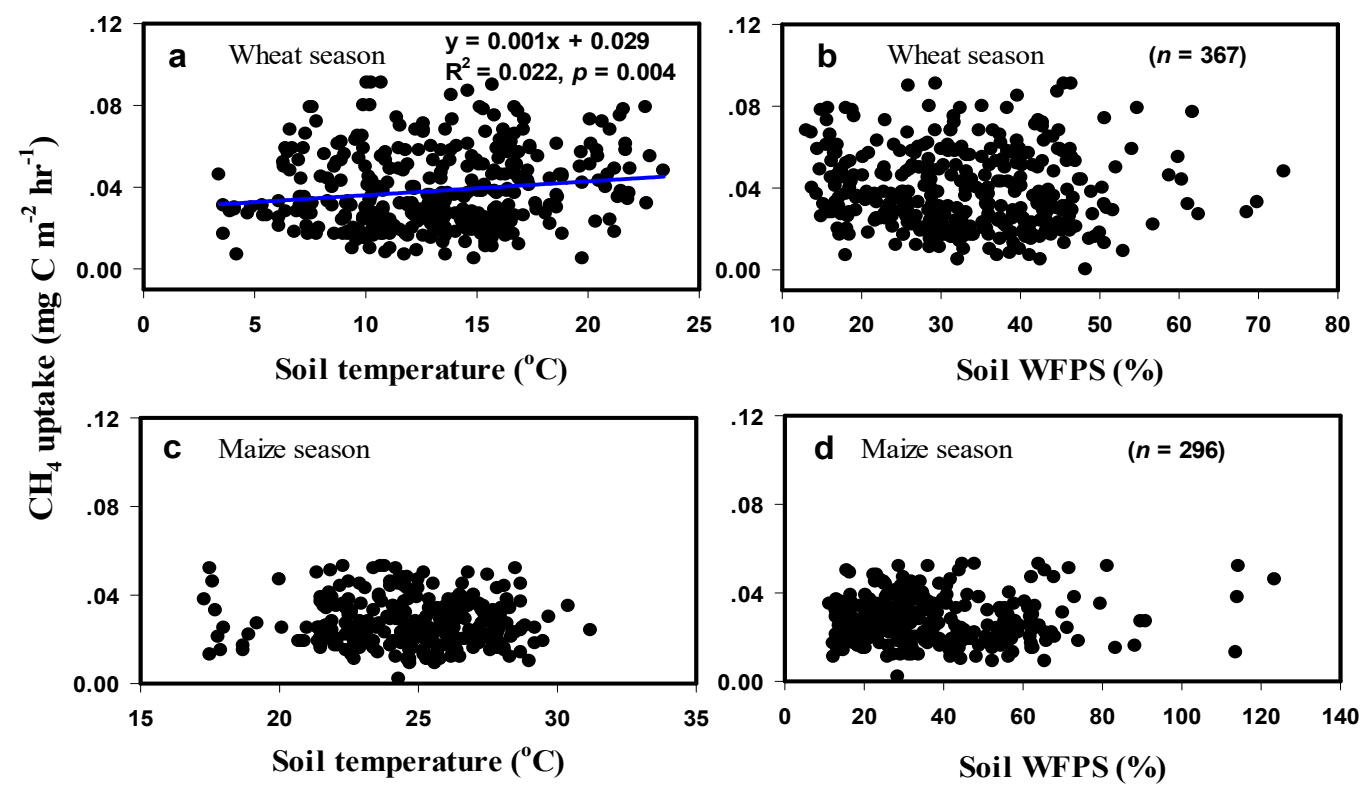

Figure 6. Relationships between $\mathrm{CH}_{4}$ uptake, soil temperature, and soil water-filled pore space (WFPS) in the wheat season $(\mathbf{a}, \mathbf{b})$ and in maize season $(\mathbf{c}, \mathbf{d})$ for the wheat and the maize seasons across the four treatments over the two-year period from 2016-2018.
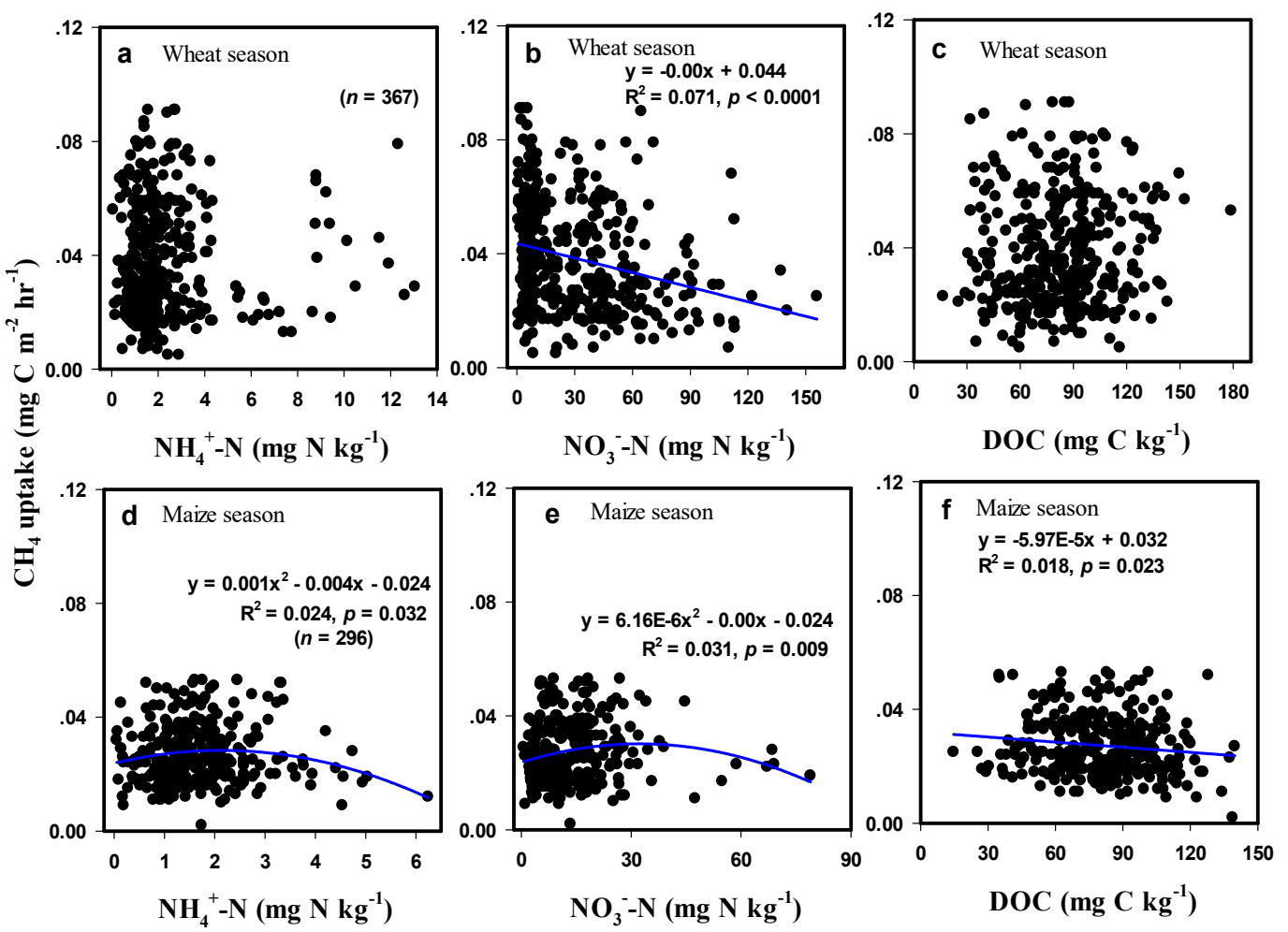

Figure 7. Relationships between $\mathrm{CH}_{4}$ uptake and $\mathrm{NH}_{4}{ }^{+}-\mathrm{N}, \mathrm{NO}_{3}{ }^{-}-\mathrm{N}$, and DOC content and soil in the wheat season $(\mathbf{a}-\mathbf{c})$ and in the maize season $(\mathbf{d}-\mathbf{f})$ for the wheat and the maize seasons across the four treatments over the two-year period from 2016-2018. 

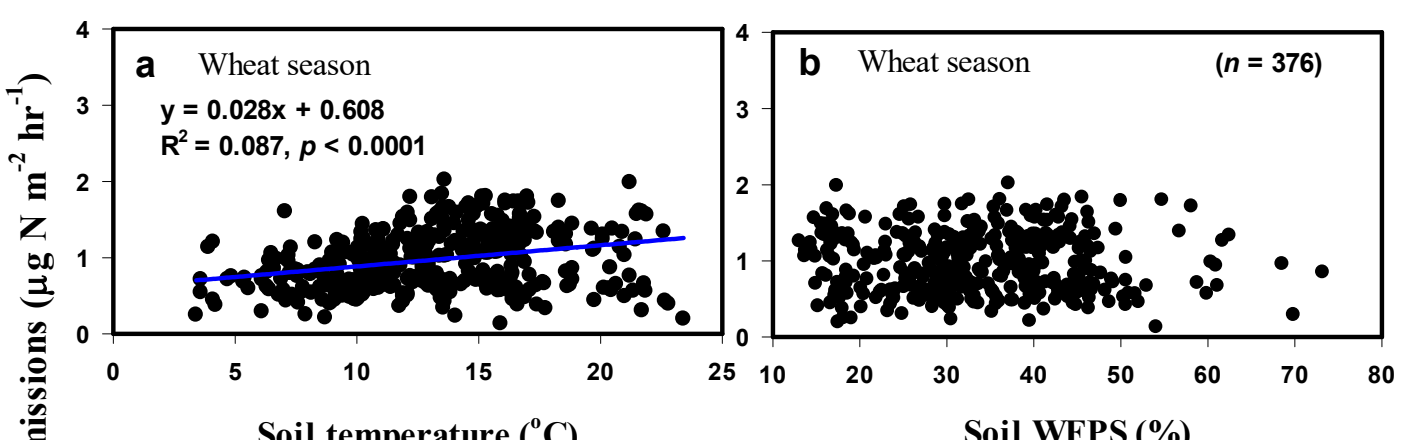

Soil temperature $\left({ }^{0} \mathrm{C}\right)$
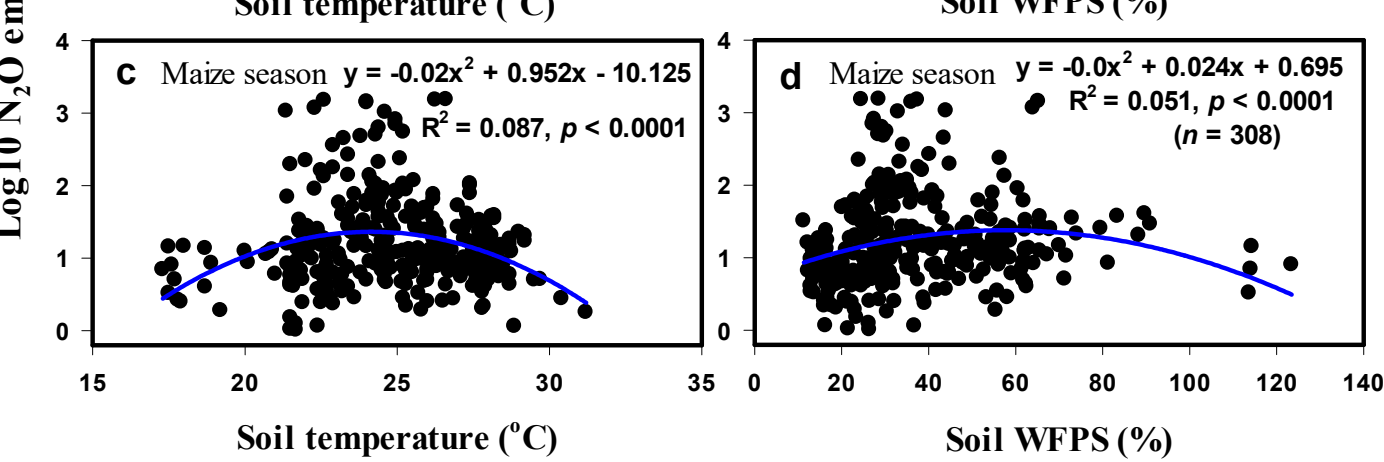

Figure 8. Relationships between $\mathrm{N}_{2} \mathrm{O}$ emissions, soil temperature, and soil water-filled pore space (WFPS) in the wheat season $(\mathbf{a}, \mathbf{b})$ and in the maize season $(\mathbf{c}, \mathbf{d})$ for the wheat and the maize seasons across the four treatments over the two-year period from 2016-2018.
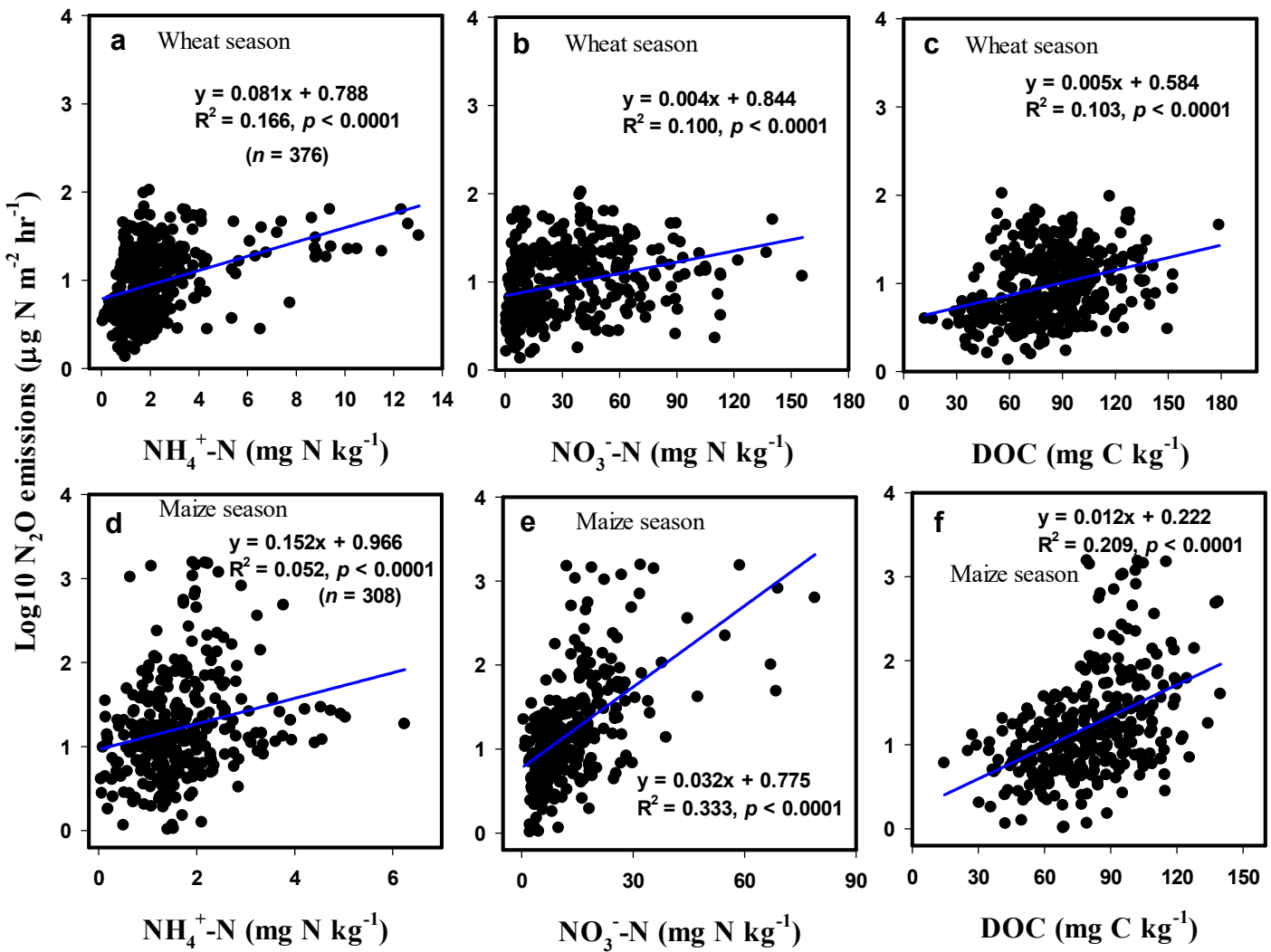

Figure 9. Relationships between $\mathrm{N}_{2} \mathrm{O}$ emissions and $\mathrm{NH}_{4}{ }^{+}-\mathrm{N}, \mathrm{NO}_{3}{ }^{-}-\mathrm{N}$, and DOC content and soil in the wheat season $(\mathbf{a}-\mathbf{c})$ and in the maize season $(\mathbf{d}-\mathbf{f})$ for the wheat and the maize seasons across the four treatments over the two-year period from 2016-2018. 


\section{Discussion}

\section{1. $\mathrm{On}_{\mathrm{CH}}$ Fluxes}

The average annual $\mathrm{CH}_{4}$ fluxes of the four treatments ranged from -2.6 to $-3.0 \mathrm{~kg} \cdot \mathrm{C} \cdot \mathrm{ha}^{-1} \cdot \mathrm{yr}^{-1}$ (Table 1) throughout the two-year experimental period. Comparatively, average annual $\mathrm{CH}_{4}$ fluxes from the control (CK, no amendment) significantly differed from those from the amendment treatments, which did not differ significantly from each other (Table 1). The three amendment treatments reduced $\mathrm{CH}_{4}$ fluxes by approximately $12 \%$ compared to those in the control. Similarly, Zhou et al. [12] reported similar $\mathrm{CH}_{4}$ fluxes, ranging from -1.8 to $-2.1 \mathrm{~kg} \cdot \mathrm{C} \cdot \mathrm{ha}^{-1} \cdot \mathrm{yr}^{-1}$, while Liu and colleagues [26] reported corresponding $\mathrm{CH}_{4}$ fluxes from -1.5 to $-1.8 \mathrm{~kg} \cdot \mathrm{C} \cdot \mathrm{ha}^{-1} \cdot \mathrm{yr}^{-1}$ in a wheat-maize rotational system under the application of similar organic amendments. The results from these studies support the assumption that cropland with wheat-maize rotational systems had the smallest $\mathrm{CH}_{4}$ fluxes and support the hypothesis that rain-fed agricultural soil generally acts as a $\mathrm{CH}_{4} \operatorname{sink}[11,13]$. The smallest $\mathrm{CH}_{4}$ fluxes in our experimental site resulted from the relatively high $\mathrm{CH}_{4}$ oxidation rates associated with light sandy soil, which promotes $\mathrm{CH}_{4}$ production diffusion within the subsoil during methanogenesis [12]. $\mathrm{CH}_{4}$ uptake and soil temperature exhibited significant linear relationships during the winter wheat season throughout the two-year experimental period (Figure 6a), indicating that $\mathrm{CH}_{4}$ uptake increased linearly with an increase in soil temperature. Similar significant relationships between $\mathrm{CH}_{4}$ uptake and soil temperature during the wheat season were detected by Zhou and co-workers [8] via long-term $\mathrm{CH}_{4}$ emission measurements. Nevertheless, our study did not find a correlation between $\mathrm{CH}_{4}$ uptake and soil temperature during the summer maize season (Figure $6 b$ ) or the WFPS of soil during either the winter wheat or the summer maize season (Figure $6 c, d$ ).

Moreover, although $\mathrm{CH}_{4}$ uptake was negatively correlated with inorganic $\mathrm{NO}_{3}{ }^{-}-\mathrm{N}$ content in the soil (Figure $7 \mathrm{~b}$ ), $\mathrm{CH}_{4}$ uptake did not correlate with soil inorganic $\mathrm{N}$ (i.e., $\mathrm{NH}_{4}{ }^{+}-\mathrm{N}$ and DOC) content during the winter wheat season (Figure 7a,c). Conversely, we found that $\mathrm{CH}_{4}$ uptake was significantly correlated with soil $\mathrm{NH}_{4}{ }^{+}-\mathrm{N}, \mathrm{NO}_{3}{ }^{-}-\mathrm{N}$, and DOC contents during the summer maize season (Figure $7 \mathrm{~d}-\mathrm{f}$ ). This indicated that $\mathrm{NH}_{4}{ }^{+}-\mathrm{N}, \mathrm{NO}_{3}{ }^{-}-\mathrm{N}$, and DOC contents in soil are regulatory factors that influence $\mathrm{CH}_{4}$ fluxes during the maize growing season in Eutric Regosols. Given that $\mathrm{CH}_{4}$ uptake from cropland is both the main $\mathrm{C}$ and energy sources of methanotrophs, $\mathrm{CH}_{4}$ uptake decreases when significant changes (i.e., conversion from $\mathrm{CH}_{4}$ to $\mathrm{NH}_{4}{ }^{+}-\mathrm{N}$ ) occur in soil substrates, as reported by $\mathrm{Hu}$ [27]. Additionally, Aronson and Helliker [28] demonstrated that this mechanism is more critical for cropping systems in cropland Eutric Regosols. Moreover, previous studies confirmed the existence of similar structures between $\mathrm{CH}_{4}$ and $\mathrm{NH}_{4}{ }^{+} \mathrm{N}$, while the preference of most methanotrophs is to oxidize $\mathrm{NH}_{4}{ }^{+}-\mathrm{N}$ (rather than $\mathrm{CH}_{4}$ ) under a higher $\mathrm{NH}_{4}{ }^{+}-\mathrm{N}$ to $\mathrm{CH}_{4}$ ratio [29,30]. More studies are necessary to better understand the interactions between soil temperature and soil $\mathrm{NH}_{4}{ }^{+}-\mathrm{N}, \mathrm{NO}_{3}{ }^{-}-\mathrm{N}$, and DOC contents in regulating $\mathrm{CH}_{4}$ uptake in cropland Eutric Regosols.

\section{2. $\mathrm{On} \mathrm{N}_{2} \mathrm{O}$ Emissions}

In this study, both seasonal and annual $\mathrm{N}_{2} \mathrm{O}$ emissions differed significantly among the four treatments (Table 1). For the four treatments, the average annual $\mathrm{N}_{2} \mathrm{O}$ emissions ranged from 0.4 to $4.6 \mathrm{~kg} \cdot \mathrm{N} \cdot \mathrm{ha}^{-1} \cdot \mathrm{yr}^{-1}$ throughout the two-year experimental period. Similar ranges have been reported, such as from 0.14 to $1.88 \mathrm{~kg} \cdot \mathrm{N} \cdot \mathrm{ha}^{-1} \cdot \mathrm{yr}^{-1}$ [12], from 0.56 to $3.01 \mathrm{~kg} \cdot \mathrm{N} \cdot \mathrm{ha}^{-1} \cdot \mathrm{yr}^{-1}$ [14], and from 0.5 to $2.2 \mathrm{~kg} \cdot \mathrm{N} \cdot \mathrm{ha}^{-1}[31]$, for wheat-maize cropping systems under different organic fertilization treatments. Compared to the control (CK, no amendment), the NPK, CRNPK, and OMNPK treatments all exhibited a significant increase in average annual $\mathrm{N}_{2} \mathrm{O}$ emissions, specifically by $69 \%, 76 \%$, and $90 \%$, respectively (Table 1). In this study, the mean $\mathrm{EF}_{\mathrm{d}}$ varied from $0.28-0.50 \%$ during the winter wheat season and from $0.30-2.05 \%$ during the summer maize season; these values are significantly higher than the results from wheat-maize cropping systems reported by Hu et al. [32] (i.e., from $0.45-0.59 \%$ ) and Gao et al. [25] (i.e., from $0.17-0.53 \%$ ) in the North China Plain. The slight differences reported in OMNPK treatments 
for $\mathrm{N}_{2} \mathrm{O}$ emissions by different studies can be explained by the long-term incorporation of CRNPK and OMNPK as organic fertilizers, resulting in an increase in $\mathrm{N}_{2} \mathrm{O}$ emissions [33-35].

Compared to the findings for the winter wheat season, the highest average annual $\mathrm{N}_{2} \mathrm{O}$ emission observed in the OMNPK treatment during the summer maize season was three-fold greater than those in the NPK and CRNPK treatments (Table 1, Figure 3). The mean $\mathrm{EF}_{\mathrm{d}}$ values for OMNPK during the winter wheat and summer maize seasons were $0.28 \%$ and $2.05 \%$, respectively, while these values were lower than $1 \%$ in the winter wheat season and higher than $1 \%$ in the summer maize season in a report by the Intergovernmental Panel on Climate Change (IPCC) [36]. The highest $\mathrm{N}_{2} \mathrm{O}$ emissions observed in the OMNPK treatment resulted from the energy provided by organic amendments to soil microorganisms being used to increase microbial biomass and $\mathrm{N}$ availability during soil $\mathrm{N}_{2} \mathrm{O}$ production via nitrification and denitrification processes [12,16]. It is interesting to note that the average annual $\mathrm{N}_{2} \mathrm{O}$ emission from the CRNPK treatment was $1.80 \mathrm{~kg} \cdot \mathrm{N} \cdot \mathrm{ha}^{-1} \cdot \mathrm{yr}^{-1}$, which was within the range of 0.20 to $4.54 \mathrm{~kg} \cdot \mathrm{N} \cdot \mathrm{ha}^{-1} \cdot \mathrm{yr}^{-1}$ reported by Huang and colleagues [13], but higher than the range of 0.29 to $1.25 \mathrm{~kg} \cdot \mathrm{N} \cdot \mathrm{ha}^{-1} \cdot \mathrm{yr}^{-1}$ reported by Htun and co-workers [9] in wheat-maize systems under crop residue returning agricultural practices. Moreover, Huang et al. [37] demonstrated that the application of crop residue with a high $\mathrm{C} / \mathrm{N}$ ratio can induce soil microbes to stimulate $\mathrm{N}$ immobilization under mineral fertilizers application. The decrease in $\mathrm{N}_{2} \mathrm{O}$ emissions observed in the CRNPK treatment was caused by the organic $\mathrm{C}$ added, resulting in the full stimulation of denitrification through the reduction of $\mathrm{N}_{2} \mathrm{O}$ to $\mathrm{N}_{2}$. Moreover, the organic $\mathrm{C}$ added did not heighten the microbial competition driven inorganic $\mathrm{N}$ immobilization of $\mathrm{NH}_{4}{ }^{-}-\mathrm{N}$ for nitrification or $\mathrm{NO}_{3}{ }^{-}-\mathrm{N}$ for denitrification [38-40]. The average $\mathrm{EF}_{\mathrm{d}}$ in the CRNPK treatment during both the winter wheat season and the summer maize season was $0.50 \%$ and $0.42 \%$, respectively, which was $1 \%$ lower than that reported by the IPCC [36].

Regarding the temporal and spatial heterogeneity in environmental factors, we found strong linear relationships between $\mathrm{N}_{2} \mathrm{O}$ emissions and soil temperature (Figure 8a), but these relationships were not associated with the WFPS of soil during the winter wheat season (Figure 8b). Additionally, Zhou and colleagues [8] found significant relationships between $\mathrm{N}_{2} \mathrm{O}$ emissions and soil temperature during the winter wheat season in their study with long-term $\mathrm{N}_{2} \mathrm{O}$ emission monitoring in wheat-rice cropping systems. During the summer maize season, we found correlations for $\mathrm{N}_{2} \mathrm{O}$ emissions with soil temperature and the soil WFPS (Figure 8c,d), which confirmed that soil temperature and soil WFPS controlled intra and inter seasonal variation in $\mathrm{N}_{2} \mathrm{O}$ emissions.

Significant linear relationships were also detected between $\mathrm{N}_{2} \mathrm{O}$ emissions and soil inorganic $\mathrm{N}$ (i.e., $\mathrm{NH}_{4}{ }^{+}-\mathrm{N}$ and $\mathrm{NO}_{3}{ }^{-}-\mathrm{N}$ ) and DOC contents during both the winter wheat season (Figure $9 \mathrm{a}-\mathrm{c}$ ) and the summer maize season (Figure $9 \mathrm{~d}-\mathrm{f}$ ) across the four treatments throughout the two-year experimental period. This finding showed that variations in soil $\mathrm{NH}_{4}{ }^{+}-\mathrm{N}, \mathrm{NO}_{3}{ }^{-}-\mathrm{N}$, and $\mathrm{DOC}$ contents throughout the two-year experimental period did not affect intra or inter seasonal $\mathrm{N}_{2} \mathrm{O}$ emissions in this study. Thus, increases in soil $\mathrm{NH}_{4}{ }^{+}-\mathrm{N}, \mathrm{NO}_{3}{ }^{-}-\mathrm{N}$, and DOC contents resulted in an increase in Eutric Regosol $\mathrm{N}_{2} \mathrm{O}$ emissions. Moreover, our results also showed that both soil temperature and WFPS as well as soil $\mathrm{NH}_{4}{ }^{+}-\mathrm{N}, \mathrm{NO}_{3}{ }^{-}-\mathrm{N}$, and DOC contents regulate cropland $\mathrm{N}_{2} \mathrm{O}$ emissions. Other studies have also shown that soil temperature, WFPS, $\mathrm{NH}_{4}{ }^{+}-\mathrm{N}, \mathrm{NO}_{3}{ }^{-}-\mathrm{N}$, and DOC are all key controllers of $\mathrm{N}_{2} \mathrm{O}$ emissions from cropland [41-43]. Conversely, Yao et al. [44] showed that $\mathrm{N}_{2} \mathrm{O}$ emissions are controlled not only by individual environmental factors, such as soil temperature, WFPS, inorganic $\mathrm{N}$, and dissolved organic $\mathrm{C}$ availability, but also by concurrent interactions between these factors. Thus, the aim of our study was to summarize the combined effects of environmental factors on Eutric Regosols.

\subsection{GWP and Yield-Scaled GWP}

The GWP was lower during the winter wheat season than during the summer maize season across all four treatments and throughout the two-year experimental period (Table 2). On average, the GWP across all four treatments throughout the two-year experimental period during the winter wheat season was $0.17 \mathrm{Mg} \cdot \mathrm{CO}_{2}$-eq.ha ${ }^{-1}$, which was significantly lower than that reported 
by [12] (i.e., $0.3 \mathrm{Mg} \cdot \mathrm{CO}_{2}$-eq.ha ${ }^{-1}$ ) and [2] (i.e., $0.66 \mathrm{Mg} \cdot \mathrm{CO}_{2}$-eq.ha ${ }^{-1}$ ). Moreover, the average GWP across all four treatments throughout the two-year experimental period during the summer maize season was $0.49 \mathrm{Mg} \cdot \mathrm{CO}_{2}$-eq.ha ${ }^{-1}$, which was significantly higher than that reported by Zhou et al. [12] (i.e., $0.38 \mathrm{Mg} \cdot \mathrm{CO}_{2}$-eq.ha ${ }^{-1}$ ) and in a metanalysis by Linquist and colleagues [2] (i.e., $1.40 \mathrm{Mg} \cdot \mathrm{CO}_{2}$-eq.ha ${ }^{-1}$ ). The GWP during the summer maize season was approximately three-fold greater than that during the winter wheat season, which was similar to findings from Linquist and colleagues [2]. Throughout the two-year experimental period, the OMNPK treatment exhibited a significantly higher GWP than the other treatments (Table 2). The mean annual GWP across all four treatments was $0.75 \mathrm{Mg} \cdot \mathrm{CO}_{2}$-eq.ha ${ }^{-1}$, in the range reported by Linquist and colleagues [2] (i.e., 0.003 to $4.40 \mathrm{Mg} \cdot \mathrm{CO}_{2}$-eq $\cdot \mathrm{ha}^{-1}$ ) from a metanalysis of 62 studies and 328 global observations. The highest $\mathrm{N}_{2} \mathrm{O}$ emission values observed during the summer maize season contributed to the significantly higher GWP in the OMNPK treatment than in the other treatments. The main difference in GWP between the winter wheat season and the summer maize season was due to emissions of $\mathrm{N}_{2} \mathrm{O}$, the dominant greenhouse gas emitted under rain-fed agricultural conditions. Nonetheless, this study did not include the GWP for fertilizer production or other components for net GWP determination, as previously reported by Huang and colleagues [13]. Further studies are needed to integrate GWP for fertilizer production, power and fuel, soil organic carbon changes, and pesticides to fully characterize net GWP in Eutric Regosols.

The yield-scaled GWP was consistently lower during the winter wheat season than during the summer maize season. For all four treatments, the average yield-scaled GWP throughout the two-year experimental period during the winter wheat season was $64 \mathrm{~kg} \cdot \mathrm{CO}_{2}-\mathrm{eq} \cdot \mathrm{Mg}^{-1}$ grain, which was lower than that reported by Zhou et al. [12] (i.e., $82 \mathrm{~kg} \cdot \mathrm{CO}_{2}$-eq $\cdot \mathrm{Mg}^{-1}$ grain) and significantly lower than that reported by Linquist and colleagues [2] (i.e., $166 \mathrm{~kg} \cdot \mathrm{CO}_{2}$-eq. $\mathrm{Mg}^{-1}$ grain). Moreover, the average yield-scaled GWP value for all four treatments throughout the two-year experimental period during the summer maize season was $122 \mathrm{~kg} \cdot \mathrm{CO}_{2}-\mathrm{eq} \cdot \mathrm{Mg}^{-1}$ grain, which was higher than that reported by Zhou et al. [12] (i.e., $84 \mathrm{~kg} \cdot \mathrm{CO}_{2}$-eq. $\mathrm{Mg}^{-1}$ grain) and lower than that reported by Linquist and colleagues [2] (i.e., $185 \mathrm{~kg} \cdot \mathrm{CO}_{2}$-eq. $\mathrm{Mg}^{-1}$ grain). In our study, average yield-scaled GWP values varied significantly among the four treatments, demonstrating the importance of conducting further yield-scaled studies applying a greater quality and quantity of organic amendments with which to identify the optimum greenhouse gas (GHG) and grain yield values when selecting mitigation strategies. Our study showed that the average annual yield-scaled GWP value accounted for $87 \%$ of grain yield (Table 2). Other studies have further shown that lower yield-scaled GWP values lead to approximately $90 \%$ of the maximum potential grain yield [2,45]. Several studies have recommended the use of yield-scaled GWP when evaluating $\mathrm{CH}_{4}$ and $\mathrm{N}_{2} \mathrm{O}$ emission mitigation without compromising grain yields from cropland $[2,11,22]$.

\section{Conclusions}

The four treatments evaluated in this study had various effects on seasonal and annual $\mathrm{CH}_{4}$ and $\mathrm{N}_{2} \mathrm{O}$ emissions, GWP, and yield-scaled GWP. $\mathrm{N}_{2} \mathrm{O}$ emissions made the greatest contribution to GWP in the OMNPK treatment (i.e., the pig slurry combined with mineral fertilizer treatment) during the summer maize season. Moreover, both the winter wheat and summer maize seasons exhibited distinct patterns of spatiotemporal variability in $\mathrm{N}_{2} \mathrm{O}$ emissions. The results revealed significant

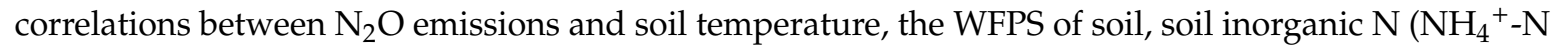
and $\mathrm{NO}_{3}{ }^{-}-\mathrm{N}$ ), and soil DOC during both the winter wheat and summer maize seasons. Given the short time span of this study (two years), long-term observations of soil organic carbon stock changes associated with greenhouse gas emissions under organic amendment applications to croplands of Eutric Regosols are necessary to determine the $C$ inputs and mineralization equilibrium.

Supplementary Materials: The following are available online at http://www.mdpi.com/2073-4433/11/6/614/s1, Table S1: Mean seasonal and annual variation of soil temperature $\left({ }^{\circ} \mathrm{C}\right)$, soil water-filled pore space (WFPS, \%), methane emissions $\left(\mathrm{CH}_{4}\right)$, and nitrous oxide $\left(\mathrm{N}_{2} \mathrm{O}\right)$ emissions for the four treatments over the two-year period 
from 2016-2018. Table S2: Mean seasonal and annual variation of soil ammonia nitrogen $\left(\mathrm{NH}_{4}{ }^{+}-\mathrm{N}\right)$, nitrate nitrogen $\left(\mathrm{NO}_{3}{ }^{-}-\mathrm{N}\right)$, and dissolved organic (DOC) contents for the four treatments over the two-year period from 2016-2018.

Author Contributions: Conceptualization, H.B. and B.Z.; data curation, H.B. and Y.W., formal analysis, H.B. and Y.W.; funding acquisition, B.Z. and J.T.; methodology, H.B., X.R., and Y.W.; supervision, B.Z. and J.T.; writing-original draft, H.B; writing-review and editing, H.B., Y.W., J.T., and B.Z. All authors have read and agreed to the published version of the manuscript.

Funding: This research was funded by the National Key R\&D Program (Grant No. 2016YFD0200309-7 and Grant No. 2018YFD0200700).

Acknowledgments: The authors would like to acknowledge the CAS-TWAS President's Fellowship for international students. The authors greatly appreciate the constructive comments from anonymous reviewers, which helped improved this manuscript.

Conflicts of Interest: The authors declare no conflicts of interest.

\section{References}

1. Cassman, K.G.; Dobermann, A.; Walters, D.T.; Yang, H. Meeting cereal demand while protecting natural resources and improving environmental quality. Annu. Rev. Environ. Resour. 2003, 28, 315-358. [CrossRef]

2. Linquist, B.; Van Groenigen, K.J.; Adviento-Borbe, M.A.; Pittelkow, C.; Van Kessel, C. An agronomic assessment of greenhouse gas emissions from major cereal crops. Glob. Chang. Biol. 2012, 18, $194-209$. [CrossRef]

3. Odhiambo, J.J.; Magandini, V.N. An assessment of the use of mineral and organic fertilizers by smallholder farmers in Vhembe district, Limpopo province, South Africa. Afr. J. Agric. Res. 2008, 3, 357-362.

4. Smith, P.; Martino, D.; Cai, Z.; Gwary, D.; Janzen, H.; Kumar, P.; McCarl, B.; Ogle, S.; O’Mara, F.; Rice, C.; et al. Greenhouse gas mitigation in agriculture. Philos.Trans. R. Soc. B 2008, 363, 789-813. [CrossRef] [PubMed]

5. Foley, J.A.; Ramankutty, N.; Brauman, K.A.; Cassidy, E.S.; Gerber, J.S.; Johnston, M.; Mueller, N.D.; O'Connell, C.; Ray, D.K.; West, P.C.; et al. Solution for cultivated planet. Nature 2011, 478, 337-342. [CrossRef] [PubMed]

6. Reay, D.S.; Davidson, E.A.; Smith, K.A.; Smith, P.; Melillo, J.M.; Dentener, F.; Crutzen, P.J. Global agriculture and nitrous oxide emissions. Nat. Clim. Chang. 2012, 2, 410-416. [CrossRef]

7. Ravishankara, A.R.; Daniel, J.S.; Portmann, R.W. Nitrous oxide $\left(\mathrm{N}_{2} \mathrm{O}\right)$ : The dominant ozone-depleting substance emitted in the 21st century. Science 2009, 326, 123-125. [CrossRef] [PubMed]

8. Zhou, M.; Zhu, B.; Wang, X.G.; Wang, Y.Q. Long-term field measurements of annual methane and nitrous oxide emissions from a Chinese subtropical wheat-rice rotation system. Soil Biol. Biochem. 2017, 115, 21-34. [CrossRef]

9. Htun, Y.M.; Tong, Y.; Gao, P.; Xiaotang, J. Coupled effects of straw and nitrogen management on $\mathrm{N}_{2} \mathrm{O}$ and $\mathrm{CH}_{4}$ emissions of rain-fed agriculture in Northwest China. Atmos. Environ. 2017, 157, 156-166. [CrossRef]

10. Stocker, T.F.; Qin, D.; Plattner, G.K.; Tignor, M.; Allen, S.K.; Boschung, J.; Nauels, A.; Xia, Y.; Bex, V.; Midgley, P.M. (Eds.) Climate Change 2013: The Physical Science Basis. Contribution of Working Group I to the Fifth Assessment Report of the Intergovernmental Panel on Climate Change; Cambridge University Press: Cambridge, UK; New York, NY, USA, 2013.

11. Adviento-Borbe, M.A.A.; Haddix, M.L.; Binder, D.L.; Walters, D.T.; Dobermann, A. Soil greenhouse gas fluxes and global warming potential in four high-yielding maize systems. Glob. Chang. Biol. 2007, 13, 1972-1988. [CrossRef]

12. Zhou, M.; Zhu, B.; Bruggemann, N.; Dannenmann, M.; Bergman, J.; Wang, Y.Q.; Butterbach-Bahl, K. N $2 \mathrm{O}$ and $\mathrm{CH}_{4}$ emissions, and $\mathrm{NO}_{3}$ leaching on a crop-yield basis from a subtropical rain-fed wheat-maize rotation in response to different types of nitrogen fertilizer. Ecosystems 2014, 17, 286-301. [CrossRef]

13. Huang, T.; Gao, B.; Christie, P.; Ju, X. Net global warming potential and greenhouse gas intensity in a double-cropping cereal rotation as affected by nitrogen and straw management. Biogeosciences 2013, 10, 7897-7911. [CrossRef]

14. Dong, Z.; Zhu, B.; Zeng, Z. The influence of $\mathrm{N}$-fertilization regimes on $\mathrm{N}_{2} \mathrm{O}$ emissions and denitrification in rain-fed cropland during the rainy season. Environ. Sci. Proc. Impacts 2014, 16, 2545-2553. [CrossRef] [PubMed] 
15. Saggar, S. Estimation of nitrous oxide emission from ecosystems and its mitigation technologies. Agric. Ecosyst. Environ. 2010, 136, 189-191. [CrossRef]

16. Butterbach-Bahl, K.; Baggs, E.M.; Dannenmann, M.; Kiese, R.; Zechmeister-Boltenstern, S. Nitrous oxide emissions from soils: How well do we understand the processes and their controls? Philos. Trans. R. Soc. B Biol. Sci. 2013, 368, 13. [CrossRef] [PubMed]

17. Zhu, B.; Wang, Z.; Zhang, X. Phosphorus fractions and release potential of ditch sediments from different land uses in a small catchment of the upper Yangtze River. J. Soils Sed. 2012, 12, 278-290. [CrossRef]

18. Li, Z.M.; Zhang, X.W.; He, Y.R.; Tang, S.J. Purple Soil in China; Science Press: Beijing, China, 1991.

19. Zhu, B.; Wang, T.; Kuang, F.; Luo, Z.; Tang, J.; Xu, T. Measurement of nitrate leaching from a hill slope cropland in the Central Sichuan Basin, China. Soil Sci. Soc. Am. J. 2009, 73, 1419-1426. [CrossRef]

20. Wang, J.; Zhu, B.; Zhang, J.; Müller, C.; Cai, Z. Mechanisms of soil N dynamics following long-term application of organic fertilizers to subtropical rain-fed purple soil in China. Soil Biol. Biochem. 2015, 91, 222-231. [CrossRef]

21. Zhou, M.; Zhu, B.; Butterbach-bahl, K.; Zheng, X.; Wang, T.; Wang, Y. Nitrous oxide emissions and nitrate leaching from a rain-fed wheat-maize rotation in the Sichuan Basin, China. Plant Soil 2013, 362, 149-159. [CrossRef]

22. Van Groenigen, J.W.; Velthof, G.L.; Oenema, O.; Van Groenigen, K.J.; Van Kessel, C. Towards an agronomic assessment of $\mathrm{N}_{2} \mathrm{O}$ emissions: A case study for arable crops. Eur. J. Soil Sci. 2010, 61, 903-913. [CrossRef]

23. Parkin, T.B.; Venterea, R.T.; Follett, R.F. Chamber-based trace gas flux measurements. In Sampling Protocols; Follett, R.F., Ed.; USDA-Agricultural Research Service: Washington, DC, USA, 2010.

24. Wang, Y.; Wang, Y. Quick measurement of $\mathrm{CH}_{4}, \mathrm{CO}_{2}$ and $\mathrm{N}_{2} \mathrm{O}$ emissions from a short-plant ecosystem. Adv. Atmos. Sci. 2003, 20, 842-844.

25. Gao, B.; Ju, X.; Su, F.; Meng, Q.; Oenema, O.; Christie, P.; Chen, X.; Zhang, F. Nitrous oxide and methane emissions from optimized and alternative cereal cropping systems on the North China Plain: A two-year field study. Sci. Total Environ. 2014, 472, 112-124. [CrossRef] [PubMed]

26. Liu, C.; Wang, K.; Zheng, X. Responses of $\mathrm{N}_{2} \mathrm{O}$ and $\mathrm{CH}_{4}$ fluxes to fertilizer nitrogen addition rates in an irrigated wheat-maize cropping system in northern China. Biogeosciences 2012, 9, 839-850. [CrossRef]

27. Hu, R.G. Effects of fertilization on the potential of methane oxidation in upland soil. Ecol. Environ. 2004, 13, 74-77.

28. Aronson, E.L.; Helliker, B.R. Methane flux in non-wetland soils in response to nitrogen addition: A meta-analysis. Ecology 2010, 91, 3242-3251. [CrossRef] [PubMed]

29. Yang, N.; Lu, F.; He, P.J.; Shao, L.M. Response of methanotrophs and methane oxidation on ammonium application in landfill soils. Appl. Microbiol. Biotechnol. 2011, 92, 1073-1082. [CrossRef] [PubMed]

30. Sun, B.F.; Zhao, H.; Lu, Y.Z.; Fei, L.U.; Wang, X.K. The effects of nitrogen fertilizer application on methane and nitrous oxide emission/uptake in Chinese croplands. J. Integr. Agric. 2016, 15, 440-450. [CrossRef]

31. Liu, C.Y.; Yao, Z.S.; Wang, K.; Zheng, X.H. Three-year measurements of nitrous oxide emissions from cotton and wheat-maize rotational cropping systems. Atmos. Environ. 2014, 96, 201-208. [CrossRef]

32. Hu, X.K.; Su, F.; Ju, X.T.; Gao, B.; Oenema, O.; Christie, P.; Huang, B.X.; Jiang, R.F.; Zhang, F.S. Greenhouse gas emissions from a wheat-maize double cropping system with different nitrogen fertilization regimes. Environ. Pollut. 2013, 176, 198-207. [CrossRef] [PubMed]

33. Zhai, L.M.; Liu, H.B.; Zhang, J.Z.; Huang, J.; Wang, B.R. Long-term application of organic manure and mineral fertilizer on $\mathrm{N}_{2} \mathrm{O}$ and $\mathrm{CO}_{2}$ emissions in a red soil from cultivated maize-wheat rotation in China. Agric. Sci. China 2011, 10, 1748-1757. [CrossRef]

34. Ding, W.X.; Luo, J.F.; Li, J.; Yu, H.Y.; Fan, J.L.; Liu, D.Y. Effect of long-term compost and inorganic fertilizer application on background $\mathrm{N}_{2} \mathrm{O}$ and fertilizer-induced $\mathrm{N}_{2} \mathrm{O}$ emissions from an intensively cultivated soil. Sci. Total Environ. 2013, 465, 115-124. [CrossRef] [PubMed]

35. Chen, H.; Li, X.; Hu, F.; Shi, W. Soil nitrous oxide emissions following crop residue addition: A meta-analysis. Glob. Chang. Biol 2013, 19, 2956-2964. [CrossRef] [PubMed]

36. Eggleston, S.; Buendia, L.; Miwa, K.; Ngara, T.; Tanabe, K. IPCC Guidelines for National Greenhouse Gas. Inventorie; Institute for Global Environmental Strategies Hayama: Kanoyama Town, Japan, 2006; Volume 5.

37. Huang, Y.; Zou, J.W.; Zheng, X.H.; Wang, Y.S.; Xu, X.K. Nitrous oxide emissions as influenced by amendment of plant residues with different C/N ratios. Soil Biol. Biochem. 2004, 36, 973-981. [CrossRef] 
38. Burger, M.; Jackson, L.E. Microbial immobilization of ammonium and nitrate in relation to ammonification and nitrification rates in organic and conventional cropping systems. Soil Biol. Biochem. 2003, 35, 29-36. [CrossRef]

39. Ball, B.C.; Mctaggart, I.P.; Scott, A. Mitigation of greenhouse gas emissions from soil under silage production by use of organic manures or slow-release fertilizer. Soil Use Manag. 2004, 20, 287-295. [CrossRef]

40. Meijide, A.; Diez, J.A.; Sanchez-Martin, L.; Lopez-Fernandez, S.; Vallejo, A. Nitrogen oxide emissions from an irrigated maize crop amended with treated pig slurries and composts in a Mediterranean climate. Agric. Ecosyst. Environ. 2007, 121, 383-394. [CrossRef]

41. Wang, W.J.; Dalal, R.C.; Reeves, S.H.; Butterbach-Bahl, K.; Kiese, R. Greenhouse gas fluxes from an Australian subtropical cropland under long-term contrasting management regimes. Glob. Chang. Biol. 2011, 17, 3089-3101. [CrossRef]

42. Pelster, D.; Rufino, M.; Rosenstock, T.; Mango, J.; Saiz, G.; Diaz-Pines, E.; Baldi, G.; Butterbach-Bahl, K. Smallholder farms in eastern African tropical highlands have low soil greenhouse gas fluxes. Biogeosciences 2017, 14, 187-202. [CrossRef]

43. Zhou, M.; Wang, X.G.; Ke, Y.; Zhu, B. Effects of afforestation on soil nitrous oxide emissions in a subtropical montane agricultural landscape: A 3-year field experiment. Agric. For. Meteorol. 2019, 266-267, 221-230. [CrossRef]

44. Yao, Z.S.; Liu, C.Y.; Dong, H.B.; Wang, R.; Zheng, X.H. Annual nitric and nitrous oxide fluxes from Chinese subtropical plastic greenhouse and conventional vegetable cultivations. Environ. Pollut. 2015, 196, 89-97. [CrossRef] [PubMed]

45. Schellenberg, D.L.; Alsina, M.M.; Muhammad, S.; Stockert, C.M.; Wolff, M.W.; Sanden, B.L.; Brown, P.H.; Smart, D.R. Yield-scaled global warming potential from $\mathrm{N}_{2} \mathrm{O}$ emissions and $\mathrm{CH}_{4}$ oxidation for almond (Prunus dulcis) irrigated with nitrogen fertilizers on arid land. Agric. Ecosyst. Environ. 2012, 155, 7-15. [CrossRef]

(C) 2020 by the authors. Licensee MDPI, Basel, Switzerland. This article is an open access article distributed under the terms and conditions of the Creative Commons Attribution (CC BY) license (http://creativecommons.org/licenses/by/4.0/). 